\title{
Institutional investor monitoring motivation and the marginal value of cash
}

\section{Article}

\section{Accepted Version}

Creative Commons: Attribution-Noncommercial-No Derivative Works 4.0

Zeng, Y., Yin, C. and Ward, C. (2018) Institutional investor monitoring motivation and the marginal value of cash. Journal of Corporate Finance, 48. pp. 49-75. ISSN 0929-1199 doi: https://doi.org/10.1016/j.jcorpfin.2017.10.017 Available at https://centaur.reading.ac.uk/73415/

It is advisable to refer to the publisher's version if you intend to cite from the work. See Guidance on citing.

To link to this article DOI: http://dx.doi.org/10.1016/j.jcorpfin.2017.10.017

Publisher: Elsevier

All outputs in CentAUR are protected by Intellectual Property Rights law, including copyright law. Copyright and IPR is retained by the creators or other copyright holders. Terms and conditions for use of this material are defined in the End User Agreement.

\section{www.reading.ac.uk/centaur}

\section{CentAUR}

Central Archive at the University of Reading

Reading's research outputs online 


\title{
Institutional Investor Monitoring Motivation and the Marginal Value of Cash*
}

\author{
Charles Ward, Chao Yin, and Yeqin Zeng ${ }^{\dagger}$ \\ ICMA Centre, Henley Business School, University of Reading, Reading RG6 6BA, United \\ Kingdom
}

\begin{abstract}
This paper examines whether the motivation of institutional investors in monitoring a firm is positively related to the relative importance of the firm's stock in their portfolios. We find that greater motivated monitoring institutional ownership is associated with a higher marginal value of corporate cash holdings, which cannot be explained by other corporate governance measures and institution types. Further, we find that the economic effect of institutional monitoring on the marginal value of cash falls with decreasing institutions' monitoring motivation. Based on these findings, we construct a monitoring motivation-weighted institutional ownership measure and document a positive relation between it and the marginal value of cash. Our results are robust after controlling for the endogeneity of institutional ownership, three cash regimes, firm size, and changes in US public firms over time.
\end{abstract}

JEL classification: G23; G30; G32

Keywords: Institutional investors; Marginal value of cash; Monitoring motivation; Index switch

${ }^{*}$ We thank Jeffry Netter (the editor), an anonymous referee, Cristian Tiu, Chris Brooks, seminar participants at the ICMA Centre, and conference participates at 2017 FEBS conference and The Role of Hedge Funds and other Collective Investment Funds in the Modern World conference at Manchester University for their insightful and constructive comments. The financial support from ICMA Centre is gratefully acknowledged.

${ }^{\dagger}$ Corresponding author at: ICMA Centre, Henley Business School, University of Reading, Reading, Berkshire RG6 6BA, United Kingdom. Tel. +44(0)118 378 4378. E-mail addresses: y.zeng@icmacentre.ac. uk (Y. Zeng), c.ward@icmacentre.ac.uk (C. Wards), c.yin@icmacentre.ac.uk (C. Yin). 


\section{Introduction}

By the end of the fiscal year 2015, the aggregate cash holdings reported by nonfinancial and non-utility firms listed on the New York Stock Exchange (NYSE), NASDAQ, and the American Stock Exchange (AMEX) had reached \$2.3 trillion, representing 22.4\% of total firm assets and equivalent to $12.5 \%$ of annual US GDP. Firms may hold more cash or other liquid assets for the precautionary motive should they face higher cash flow uncertainty, market competition, or credit constraints (e.g., Haushalter et al., 2007; Bates et al., 2009; Harford et al., 2014). However, the use of cash is mainly at the managers' discretion. Firm managers may either directly take the cash in the form of perks or excessive salaries, or invest it in projects that do not maximize shareholders' profits. Therefore, the managerial agency problems may reduce the value of corporate cash holdings.

This paper studies how institutional investor attention affects their governance role in monitoring corporate cash holdings. With the growth of institutional investors in the US stock market, large shareholders are likely to be active in firm governance. ${ }^{1}$ Previous studies have usually measured institutional monitoring by total institutional ownership or the ownership of institutional investors with similar characteristics, such as institution types, investment horizon, activeness in the engagement with firms, and a certain ownership threshold (e.g., Bushee, 1998; Chen et al., 2007; Cremers and Petajisto, 2009; Cronqvist and Fahlenbrach, 2009). However, institutional investors hold a large number of stocks in their portfolio. $^{2}$ Recent theoretical and empirical studies support the view that institutional investor attention is a scarce resource (Sims, 2003; Kacperczyk et al., 2016; Kempf et al., 2017). If the optimal level of monitoring attention to a holding firm is determined by the trade-off between monitoring benefits and costs, it may not be optimal for institutional investors to distribute their monitoring attention evenly to all the stocks in their portfolios. Fich et al. (2015) show that in mergers and acquisitions (M\&A), the monitoring attention of

\footnotetext{
${ }^{1}$ Edmans and Holderness (2016) provide a detailed survey of previous studies on the role of large shareholders in corporate governance.

${ }^{2}$ On average, an institutional investor's portfolio included 219 stocks during 1980-2010 (Zeng, 2016).
} 
institutional investors to a target firm is positively associated with the relative importance of the firm's stock in their portfolios. Following Fich et al. (2015), we define a firm's most motivated monitoring institutional investors as those whose holding values in the firm account for the top $10 \%$ of their portfolios. ${ }^{3}$ If motivated monitoring institutional investors are indeed more actively engaging in firm governance than other institutional investors, then the market perceived value of cash should be higher for firms with greater motivated monitoring institutional ownership (IO).

To test the institutional investor limited attention hypothesis, we examine the following three research questions. First, is there a negative relation between institutional monitoring attention and the relative importance of firms in their portfolios? Second, does our measure of monitoring motivation vary across different institution types? Third, does motivated monitoring IO differ from other traditional corporate governance measures? There are several advantages of using the marginal value of cash as an empirical setting to answer these questions. First, the effect of motivated monitoring IO on the marginal value of cash can be measured by a dollar value perceived by stock market participants. Second, the pecuniary numbers documented in our panel sample not only contain time-varying and cross-section-varying information on the value of institutional monitoring, but also provide us with an empirical framework to examine how institutional investors allocate their monitoring attention to all firms in their portfolios. Lastly, conflicts of interest between shareholders and managers may cause firms to invest cash inefficiently (e.g., Jensen, 1986; Harford et al., 2008), so it is naturally to study whether and to what extent motivated monitoring institutional investors impinge on the value of corporate cash holdings.

Our sample includes 67,404 firm-year observations from the Centre for Research in Security (CRSP)/Compustat Merged dataset over the period 1995-2015. To quantify the effect of motivated monitoring institutional investors on firm cash holdings, we adopt Faulkender and Wang's (2006) specification and estimate the change in firm market value

\footnotetext{
${ }^{3}$ Later in the paper, we extend the top $10 \%$ cutoff and construct a general monitoring motivationweighted institutional ownership measure. Therefore we append "most" to motivated monitoring institutional investors.
} 
associated with a change of one dollar in cash holdings. ${ }^{4}$ We find strong evidence that the marginal value of cash increases with most motivated monitoring IO. Controlling for other factors, a one standard deviation increase in most motivated monitoring IO is associated with a 9.2 cents higher marginal value of cash. This economic effect is even stronger if we replace most motivated monitoring IO by either the ratio of the numbers of the most motivated monitoring institutional investors to the numbers of total institutional investors (23.7 cents), or the natural log of one plus the numbers of the most motivated monitoring institutional investors (19.9 cents).

We next examine whether the positive effect of most motivated monitoring IO on the marginal value of cash can be explained by other traditional firm governance measures. We use four proxies following the previous literature: Gompers et al.'s (2003) G-index, Bebchuk et al.'s (2009) E-index, total institutional ownership, and blockholder ownership. The positive relation between the most motivated monitoring $\mathrm{IO}$ and the marginal value of cash remains statistically and economically significant after controlling for both antitakeover indexes and other institutional ownership measures. More importantly, total institutional ownership and blockholder ownership do not have a significantly positive effect on the marginal value of cash in addition to the most motivated monitoring IO. This suggests that the motivation of an institutional investor to monitor a firm is more related to how important the firm is to the investor than how important the investor is to the firm. Our findings show that the role of the most motivated institutional investors in monitoring firm cash holdings is unlikely to be driven by the traditional firm governance measures.

We also try to determine whether our measure of institutional monitoring motivation may only be applied to a particular type of institution. According to Brickley et al.'s (1988) classification, we find that both independent and grey most motivated institutional investors have a positive association with the marginal value of cash. We further use Bushee's (1998) classification and show that all three types of most motivated monitoring

\footnotetext{
${ }^{4}$ In this paper, we use "the marginal value of cash" and "the change in firm market value associated with a change of one dollar in cash holdings" interchangeably.
} 
IO have a positive effect on the marginal value of cash, while the effect is only statistically significant for transient and quasi-indexer institutions. Our findings indicate that institutions, whose monitoring role is believed to be ineffective due to the potential business ties (grey) and short investment horizon (transient), still have a positive contribution in monitoring firms that are relatively important in their portfolios.

To explore how an institutional investor's monitoring attention to a firm changes with the firm's market value weight in the portfolio, we sort all firms in an institutional investor's portfolio into ten decile groups by their descending market value weight in the portfolio. We extend Fich et al.'s (2015) 10\% threshold and examine the allocation of monitoring attention to all the stocks in institutional portfolios. The institutional investor's monitoring attention should be higher for firms in the top decile group than for those in the bottom decile group. If firm $i$ is assigned in the decile group $j$ of an institutional investor's portfolio, we classify the institutional investor as a class $j$ investor in firm $i$, where $j$ is from 1 to 10 . Next, we identify all class $j$ investors in firm $i$ and define the total ownership of these investors as $M M I O_{i, j}$, motivated monitoring $\mathrm{IO}_{i, j}$. Our prediction is that $M M I O_{i, 1}$ $\left(M M I O_{i, 10}\right)$ should denote the ownership of institutional investors who have the strongest (weakest) motivation to monitor firm $i .^{5}$ Consistent with this prediction, we document that the positive effect of IO on the marginal value of cash decreases with institutional investors' monitoring motivation. The two highest classes $\left(M M I O_{i, 1}\right.$ and $\left.M M I O_{i, 2}\right)$ are positively related to the marginal value of cash, and the relation is statistically significant. The relation between the ownership of classes 3-5 $\left(M M I O_{i, 3}\right.$ to $\left.M M I O_{i, 5}\right)$ and the marginal value cash is not statistically significant. The relation between the ownership of classes 6-10 $\left(M M I O_{i, 6}\right.$ to $\left.M M I O_{i, 10}\right)$ and the marginal value of cash is negative and statistically significant.

We conduct a battery of robustness tests. First, our main results are robust after accounting for the endogeneity issues arising from unobserved firm characteristics and potential investor self-selection bias. We employ three identifications to mitigate any endo-

\footnotetext{
${ }^{5} M M I O_{i, 1}$ and most motivated monitoring IO are used interchangeably in the rest of our paper.
} 
geneity issues: (1) two-stage least squares (2SLS) with instrumental variables (IVs) based on the Russell index reconstitution, (2) high-dimensional fixed effects, and (3) the change in the motivated monitoring IO. Second, we use the weight of a stock in institutional portfolios as a proxy for institutional monitoring motivation and construct a monitoring motivationweighted IO. We document a positive relation between the monitoring motivation-weighted IO and the marginal value of cash. Third, Halford et al. (2016) indicate that it is important to control for cash regimes when researchers study the effect of corporate governance on the marginal value of cash. We find that the positive effect of $M M I O_{i, 1}$ on the marginal value of cash remains positive and statistically significant in the raising cash and distributing cash regimes. Fourth, we examine whether firms actually benefit from institutional monitoring and show that the most motivated monitoring institutional investors may improve the operating performance of firms through monitoring firm cash holdings. Fifth, the positive relation between $M M I O_{i, 1}$ and the marginal value of cash remains robust after controlling for firm size and its interaction with the change in cash. Sixth, we follow Dittmar and Mahrt-Smith (2007) and estimate the value of firm excess cash holdings using Fama and French's (1998) empirical method. We find that $M M I O_{i, 1}$ is positively related to the value of firm excess cash holdings.

Finally, we examine how the relation between motivated monitoring IO and the marginal value of cash is influenced by the changes in US public companies over our sample period. As Kahle and Stulz (2017) point out, US public firms have changed their policies and firm characteristics notably during 1975-2015. For example, US public companies' institutional ownership, cash holding, age, R\&D expenses, intangible assets, and profitability are very different in 2015 compared to those in 1975 or 1995 . When we examine the monitoring role of motivated institutional investors, it is important to take into consideration the consequence of the changes in firms during our sample period. Motivated by Kahle and Stulz's (2017) findings, we conduct sub-sample analyses for firms over two sample periods: 1995-2004 and 2005-2015. We also conduct sub-sample analyses for firms with high and low cash holdings, age, R\&D expenses, intangible assets, and profitability, respectively. 
We find that the relation between motivated monitoring IO and the marginal value of cash remains positive and statistically significant in all sub-samples.

Our paper makes three contributions. First, we add to the emerging literature showing that institutional monitoring attention affects their monitoring effectiveness. In particular, Fich et al. (2015) find that M\&A deal premiums and completion probabilities are positively associated with the most motivated monitoring IO of target firms. Liu et al. (2016) and Kempf et al. (2017) use the exogenous shocks to unrelated firms' stocks in an institutional investor's portfolio as a proxy for the distraction that may divert the institutional investor's monitoring attention to a firm. We contribute to this line of research by generalizing Fich et al.'s (2015) study of M\&A targets to US public firms. We show the positive impact of institutional monitoring attention on the marginal value of corporate cash holdings, as well as the mechanisms through which this outcome manifests itself. More importantly, our empirical setting helps us to examine the allocation of institutional monitoring attention among all stocks in their portfolios. We show that institutional investors' monitoring attention to a firm drops monotonically when the relative importance of the firm's stock decreases in their portfolios.

Second, we shed light on two ongoing debates. The first debate addresses on the role of passive institutional investors in corporate governance. Some previous studies suggest that passive institutional investors weaken firm corporate governance (e.g., Schmidt and Fahlenbrach, 2016), while others argue that they can still contribute to shareholder activisim (e.g., Appel et al., 2016a,b). Our paper contributes to this debate by providing evidence that both active and passive institutional investors effectively monitor firms that are relatively important in their portfolios. The second debate concerns the value of cash. Dittmar and Mahrt-Smith (2007) find that corporate governance measured by anti-takeover indexes and blockholder ownership improves the marginal value of corporate cash holdings. However, Halford et al. (2016) show that the positive relation between corporate governance and the marginal value of cash is not robust after accounting for ex post classified cash regimes. We find that not only does motivated monitoring IO improve the 
marginal value of cash after controlling for the anti-takeover indexes and blockholder ownership, but also that this positive effect remains statistically significant in Halford et al.'s (2016) raising cash and distributing cash regimes.

Third, our paper adds to the previous literature that examines the determinants of the value of corporate cash holdings, such as corporate financial policy (Faulkender and Wang, 2006), corporate governance (Dittmar and Mahrt-Smith, 2007), financial constraints and investment opportunities (Denis and Sibilkov, 2009), firm-specific and time-varying information asymmetry (Drobetz et al., 2010), corporate diversification (Duchin, 2010; Tong, 2011), accounting conservatism (Louis et al., 2012), credit rights (Kyröläinen et al., 2013), product market competition (Alimov, 2014), refinancing risk (Harford et al., 2014), the adoption of state-level business combination laws (Fich et al., 2016), internal control

over financial reporting (Gao and Jia, 2016), and cash regimes (Halford et al., 2016). In this study, we show that firms with greater institutional monitoring attention have a higher marginal value of cash. Our paper provides new insights into the role of motivated monitoring institutions in corporate activities.

The remainder of the paper is organized as follows. Section 2 describes our baseline regression, proxies for institution monitoring motivation, and sample data. Section 3 presents our main test results. Section 4 discusses the analyses we perform to assess the robustness of our main results. We conclude our paper in section 5. Appendix A provides the detailed definition of all the variables used in our empirical analyses.

\section{Research Design and Sample}

\subsection{Baseline Regression Model}

The objective of this paper is to identify the effect of motivated monitoring institutional investors on the marginal value of corporate cash holdings. Our primary regression model builds on Faulkender and Wang's (2006) empirical framework in estimating the 
value of one addition dollar of cash holdings, an approach which has been widely used in the previous literature (e.g., Dittmar and Mahrt-Smith, 2007; Denis and Sibilkov, 2009). Faulkender and Wang (2006) use ordinary least squares (OLS) regressions to examine the association between firms' excess stock returns and unexpected changes in their cash holdings, controlling for other firm-specific characteristics. We extend Faulkender and Wang's (2006) model by adding motivated monitoring IO and the interaction of it with unexpected changes in cash. Our baseline regression model (Model (1)) is described as follows:

$$
\begin{aligned}
r_{i, t}-R_{i, t}^{B}= & \beta_{0}+\beta_{1} M M I O_{i, 1, t} \times \frac{\Delta C_{i, t}}{M_{i, t-1}}+\beta_{2} M M I O_{i, 1, t}+\beta_{3} \frac{\Delta C_{i, t}}{M_{i, t-1}}+\beta_{4} \frac{\Delta E_{i, t}}{M_{i, t-1}}+ \\
& \beta_{5} \frac{\Delta N A_{i, t}}{M_{i, t-1}}+\beta_{6} \frac{\Delta R \& D_{i, t}}{M_{i, t-1}}+\beta_{7} \frac{\Delta I_{i, t}}{M_{i, t-1}}+\beta_{8} \frac{\Delta D_{i, t}}{M_{i, t-1}}+\beta_{9} \frac{\Delta N F_{i, t}}{M_{i, t-1}}+\beta_{10} \frac{C_{i, t-1}}{M_{i, t-1}} \\
& +\beta_{11} L_{i, t}+\epsilon_{i, t}
\end{aligned}
$$

where $i$ represents a firm and $t$ represents the end of a fiscal year. The dependent variable $r_{i, t}-R_{i, t}^{B}$ is the annual return on firm $i$ 's stock minus the annual return on one of the Fama and French (1993) 25 size and book-to-market portfolios to which firm $i$ belongs at the beginning of year $t$. $\Delta$ indicates a change in the corresponding variables over year $t$. $M M I O_{i, 1, t}$ is most motivated monitoring $\mathrm{IO}$ which is described in section $1, C$ is cash and marketable securities, $E$ is earnings, $N A$ is net assets, $R \& D$ is research and development expenditures, $I$ is interest expenses, $D$ is dividends, $N F$ is net financing proceeds, and $L$ is leverage. Because both the excess stock returns and firm-specific control variables are normalized by the market value of equity $(M)$ at the end of the fiscal year $t-1$, the coefficient of our independent variable of interest, $\beta_{1}$, can be interpreted as the effect of most motivated monitoring IO on the marginal value of cash. If institutional monitoring mitigates the agency problem and leads to a better use of cash, $\beta_{1}$ is expected to be positive - that is, the marginal value of cash increases with the most motivated monitoring IO. The detailed definitions of these variables are provided in Appendix A.

In our main empirical analyses, we modify our baseline regression Model (1) to account for other factors that may affect the marginal value of cash. First, Faulkender and 
Wang (2006) find that the marginal value of cash is sensitive to a firm's cash in hand and capital structure. We add the interaction terms $C_{i, t-1} \times \Delta C_{i, t} / M_{i, t-1}$ and $L_{i, t} \times \Delta C_{i, t} / M_{i, t-1}$ to control for these two factors. Second, the marginal value of cash may be associated with time-varying differences across industries. Therefore, we also control for industry and year fixed effects. Third, the unexpected change in cash is measured by the difference between $C_{i, t}$ and $C_{i, t-1}$ in Model (1). The implicit assumption is that the market expected value of $C_{i, t}$ is equal to $C_{i, t-1}$. Following Faulkender and Wang (2006), we replace $\Delta C_{i, t}$ by three alternative definitions of the unexpected change in cash. Lastly, Dittmar and MahrtSmith (2007) document a positive relation between corporate governance and the marginal value of cash. In Model (1), to differentiate our proxy for institution monitoring attention with other traditional corporate governance measures, we control for Dittmar and MahrtSmith's (2007) two corporate governance measures: anti-takeover indexes and blockholder ownership.

\subsection{Proxies for Institutional Investor Monitoring Motivation}

As discussed in section 1, an institutional investor has a stronger incentive to monitor a firm that is relatively more important than the other firms held in its portfolio. To measure the relative importance of a holding firm, we sort all firms in an institutional investor's portfolio into decile groups by their descending market value weights in the portfolio. Firms assigned in decile group 1 (10) have the highest (lowest) weights by market value and therefore the most (least) importance to the institutional investor. In our main analyses, we focus on the ownership of most motivated institutional investors $\left(M M I O_{i, 1}\right)$, which generally follows Fich et al.'s (2015) definition of motivated monitoring institutional investors in M\&A targets. Our untabulated results suggest that, on average, firms in decile 1 groups account for about $41 \%$ market value of institutional investors' overall portfolio holdings. It is reasonable to assume that institutional monitoring incentives are concentrated on these firms.

We also use two alternative proxies of most motivated monitoring IO to confirm 
that our results are not driven by the definition of $M M I O_{i, 1}$. The first alternative proxy is the proportion of the most motivated monitoring institutional investors $\left(P M M I_{i, 1}\right)$, defined as the ratio of the number of firm $i$ 's class 1 institutional investors $\left(N M M I_{i, 1}\right)$ to the number of all institutional investors holding firm $i$ 's stock. Our second alternative proxy is the natural log of one plus the number of firm $i$ 's class 1 institutional investors $\left(\operatorname{Ln}\left(1+N M M I_{i, 1}\right)\right)$.

\subsection{Data and Summary Statistics}

Our firm-year observations are collected from the CRSP/Compustat Merged dataset. We restrict our sample to the firms with stock return data from CRSP and annual accounting information from Compustat. To calculate excess stock returns, we obtain the benchmark break points and benchmark portfolio returns from Kenneth French's data library. We collect quarterly institutional investor holding data from Thomson Reuters s34 files. To obtain the classification of institutional investors, we extract data from Brian Bushee's personal website. To construct corporate governance indexes, we use data from Institutional Shareholder Services (ISS, formerly RiskMetrics). Our sample period is from 1995 to 2015 because we use firms switching between Russell indexes as our IVs. The Russell index constituent data are from Bloomberg and available for use starting from 1995. Following the standard sample selection criteria in the value of cash and institutional investor studies (e.g., Faulkender and Wang, 2006; Dittmar and Mahrt-Smith, 2007; Cella et al., 2013), we exclude firms in financial (SIC between 6000 and 6999) and public utility (SIC between 4900 and 4999) industries and restrict our sample to firms listed on the NYSE, NASDAQ, and AMEX. Similarly to Faulkender and Wang (2006), we delete

firm-year observations with negative net assets, negative equity, or negative dividend. After applying these data selection criteria, there are 67, 404 firm-year observations included in our final sample. We follow the literature and winsorize the accounting and stock return variables at the $1 \%$ and $99 \%$ levels. All data are converted to real values in 2016 dollars 
using the consumer price index from the website of the Federal Reserve Bank of St. Louis. ${ }^{6}$

Figure 1 plots the increasing trend of US corporate cash holdings over our sample period. The total nominal cash holdings increase by $456.6 \%$ (from $\$ 490.1$ billion in 1995 to $\$ 2,237.6$ billion in 2015). The total real cash holdings in 2016 dollars increase by $295.2 \%$ (from $\$ 773.9$ billion in 1995 to $\$ 2284.6$ billion in 2015). We also observe a significant growth in the cash to total asset ratios over our sample period, from $14.7 \%$ in 1995 to 22.4 $\%$ in 2015. Given the substantial cash holdings of US firms in our sample, the effect of motivated monitoring institutional investors on the marginal value of cash documented in our study is of great economic importance.

Table 1 presents the summary statistics on the variables used in our empirical analyses. We observe that the average $M M I O_{j}$ decreases with decreasing institutional monitoring motivation, from $10.6 \%\left(M M I O_{1}\right)$ to $0.8 \%\left(M M I O_{10}\right)$. Although most of our sample period does not overlap the sample period of 1971-2001 in Faulkender and Wang (2006), the summary statistics of firm-specific variables in these two samples are relatively comparable. The mean and median excess returns of our sample firms are $-0.1 \%$ and $-9 \%$, while Faulkender and Wang (2006) report a mean (median) of $-0.5 \%(-8.5 \%)$. The mean and median of the independent variables in our sample are: Cash holdings (21.3\% and 11.1\%), $\Delta$ Cash holdings $(0.6 \%$ and $0.1 \%), \Delta$ Earnings $(1.6 \%$ and $0.5 \%), \Delta$ Net assets $(1.7 \%$ and $1.4 \%), \Delta R \& D(-0.1 \%$ and $0.0 \%), \Delta$ Interest expenses $(0.1 \%$ and $0.0 \%), \Delta$ Dividends $(0.0 \%$ and $0.0 \%$ ), Leverage (20.3\% and $13.1 \%$ ), and Net financing (3.6\% and $0.1 \%)$.

\section{Main Results}

\subsection{Baseline Regression Results}

We start our empirical analyses by replicating Faulkender and Wang's (2006) main results over their sample period of 1971-2001. Column (1) of Table 2 shows that an additional dollar of cash is valued by the stock market at 77.2 cents, consistent with

\footnotetext{
${ }^{6}$ When we started working on this paper, we had the consumer price index data up to 2016.
} 
Faulkender and Wang's (2006) finding of 75.1 cents. After controlling for cash on hand and leverage, the marginal value of cash in column (2) is $\$ 1.07(=1.529+(-0.728 \times$ $0.184)+(-1.609 \times 0.203))$, which is comparable to $\$ 0.94$ in Faulkender and Wang (2006). ${ }^{7}$

The primary objective of our study is to estimate the effect of motivated monitoring institutional investors on the marginal value of cash holdings. Column (3) of Table 2 presents the results from estimating Model (1) using OLS. Then we extend Model (1) by controlling for the industry and year fixed effects in column (4) and further include two interaction terms to control for firms' cash in hand and capital structure in column (5). In columns (3)-(5), the coefficients of the independent variable of interest $\left(M M I O_{1} \times \Delta\right.$ Cash holdings) are all positive and statistically significant at the $1 \%$ or $5 \%$ level. Based on the estimates in column (3), a change of one dollar in cash holdings is associated with an additional change of $7.6(=0.714 \times 0.106 \times 100)$ cents in market value for a firm with an average motivated monitoring IO. After we add the additional control variables in columns (4) and (5), the marginal value of cash increases by 8.3 cents and 6.0 cents for a firm with an average most motivated monitoring IO. ${ }^{8}$

Next, we examine two alternative measures of most motivated monitoring institutional investors. In columns (6)-(8), we replace $M M I_{1}$ by $P M M I_{1}$, the number of the most motivated monitoring institutional investors in a firm divided by the total number of its institutional investors. In columns (9)-(11), we replace $M M I O_{1}$ by $\operatorname{Ln}\left(1+N M M I_{1}\right)$, the natural $\log$ of one plus the number of the most motivated monitoring institutional investors in a firm. The coefficients of $P M M I_{1} \times \Delta$ Cash holdings and $\operatorname{Ln}\left(1+N M M I_{1}\right) \times \Delta$ Cash holdings are all positive and statistically significant at the $1 \%$ level. The marginal value of cash increases by $13.8(=3.949 \times 0.035 \times 100)$ cents to 17.6 cents for a firm with an average $P M M I_{1}$. The marginal value of cash increases by 15.5

\footnotetext{
${ }^{7}$ Our replication sample size is slightly larger than Faulkender and Wang's (2006), for two reasons. First, Faulkender and Wang (2006) trim their sample variables at the $1 \%$ tails, while we winsorize our variables at the $1 \%$ and $99 \%$ tails. Second, we use the CRSP/Compustat Merged dataset, which may not have been available in 2006 .

${ }^{8}$ We also normalize $M M I O_{1}$ by firm total institutional ownership. Our baseline results are robust to the normalized measure of most motivated monitoring IO.
} 
$(=0.146 \times 1.059 \times 100)$ cents to 18.9 cents for a firm with an average $\operatorname{Ln}\left(1+N M M I_{1}\right)$. The changes in these three proxies for institutional monitoring attention also have an economically significant effect on the marginal value of cash. Columns (5), (8), and (11) imply that a one standard deviation increase in $M M I O_{1}, P M M I_{1}$, or $\operatorname{Ln}\left(1+N M M I_{1}\right)$ is associated with $9.2(=0.565 \times 0.162 \times 100)$ cents, $23.7(=3.949 \times 0.060 \times 100)$ cents, or 19.9 $(=0.146 \times 1.361 \times 100)$ cents higher marginal value of cash, respectively. ${ }^{9}$

\subsection{Alternative Measures of Expected Change in Cash}

According to Fama's (1970) efficient market hypothesis, stock prices in an informationally efficient stock market incorporate all the available information about firm future values. The value of any expected change in cash should have already been incorporated in stock prices at the beginning of the fiscal year. In Table 2, $\Delta$ Cash holdings $_{t}$, the unexpected change in cash, is the difference between Cash holdings ${ }_{t}$ and Cash holdings Cl-1 $_{\text {. An implicit }}$ assumption is that the market expected cash holdings at the end of fiscal year $t$ is equal to the actual cash holdings at the end of fiscal year $t-1$. To mitigate the concern about this implicit assumption, we follow Faulkender and Wang (2006) and use three alternative measures of expected change in cash. We thus calculate the unexpected change in cash as the difference between the actual change in cash and the expected change in cash.

Motivated monitoring institutional investors may affect multiple corporate policies, for example, the investment policy which in turn affects the valuation of cash. In our three alternative measures of expected change in cash, we directly control for firm size, growth opportunities, cash flows, capital expenditures, acquisition expenses, investment in net working capital, leverage, and industry fixed effects. The first alternative measure is the average change in cash of all firms in one of the Fama-French 25 size and book-to-market portfolios to which a firm belongs. Given that our dependent variable $r_{i, t}-R_{i, t}^{B}$ is adjusted for the same benchmark portfolio returns, it is likely that $R_{i, t}^{B}$ should already incorporate

\footnotetext{
${ }^{9}$ For brevity, we focus on $M M I O_{1}$ in the rest of our paper. Our empirical results are robust for $P M M I_{1}$ and $\operatorname{Ln}\left(1+N M M I_{1}\right)$. The economic effects of $P M M I_{1}$ and $\operatorname{Ln}\left(1+N M M I_{1}\right)$ on the marginal value of cash are more pronounced than those of $M M I O_{1}$.
} 
the information on the average change in cash of firms in the corresponding benchmark portfolio. The first alternative, $\Delta$ Alternative cash holdings $I$, is equal to the difference between $\Delta$ Cash holdings and average $\Delta$ Cash holdings for all firms in the benchmark portfolio. The second and third alternative measures are motivated by Almeida et al. (2004), who use firms' cash sources and uses of cash to predict the change in cash holdings. The expected changes in cash are the predicted values of $\Delta C$ in the following two regression models:

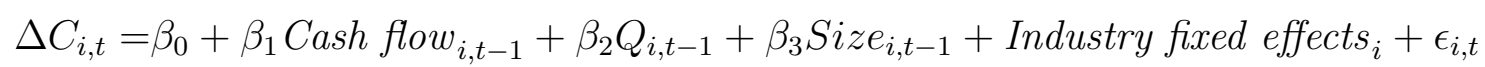

$$
\begin{aligned}
& \Delta C_{i, t}=\beta_{0}+\beta_{1} \text { Cash }_{\text {flow }_{i, t-1}}+\beta_{2} Q_{i, t-1}+\beta_{3} \text { Size }_{i, t-1}+\beta_{4} \text { Capital expenditure }_{i, t-1}+
\end{aligned}
$$

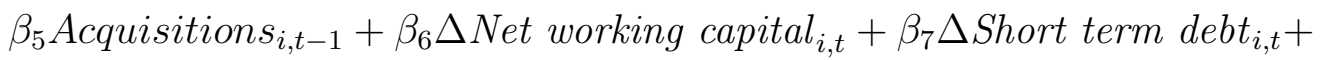

$$
\begin{aligned}
& \text { Industry fixed effects }{ }_{i}+\epsilon_{i, t}
\end{aligned}
$$

Following Faulkender and Wang (2006), all the variables in Models (2) and (3) are normalized by the market value of assets in the fiscal year $t-1$. $\Delta$ Alternative cash holdings $I I$ and $\Delta$ Alternative cash holdings III are the residuals of Models (2) and (3). ${ }^{10}$

Table 3 reports the results of estimating Model (1) with the three $\Delta$ Alternative cash holdings. All the coefficients of our variable of interest, $M M I O_{1} \times \Delta$ Alternative cash holdings, are positive and statistically significant at the $1 \%$ or $5 \%$ level. Columns (1)-(9) imply that the marginal value of cash increases by 5.3 cents to 9.0 cents for a firm with an average $M M I O_{1}$. A one standard deviation increase in $M M I O_{1}$ is associated with 8.1 cents to 13.8 cents higher marginal value of cash. The positive effect of the most motivated monitoring institutional investors on the marginal value of cash remains, both statistically and economically, significant with respect to three alternative measures of expected change in cash.

\footnotetext{
${ }^{10}$ Please refer to Almeida et al. (2004) and Faulkender and Wang (2006) for the detailed discussions of these three alternative measures.
} 


\subsection{Traditional Measures of Corporate Governance}

One concern with our results is that institutional investors may be attracted to take large stakes in firms because the firms are seen to have strong governance measures in place. Therefore, the positive effect of $M M I O_{1}$ on the marginal value of cash may be mainly driven by other corporate governance measures. Dittmar and Mahrt-Smith (2007) use anti-takeover governance indexes and blockholder ownership as two corporate governance measures. They document a positive relation between firm corporate governance and the marginal value of cash. To mitigate this concern, we examine whether most motivated monitoring IO has any positive effect on the marginal value of cash in addition to the effect of traditional corporate governance proxies. It is worth noting that our effective sample size is substantially reduced by requiring firm-year observations with corporate governance index data.

Table 4 reports the results from estimating Model (1) by controlling for corporate governance indexes and alternative institutional ownership simultaneously. In columns (1)-(3), the corporate governance index is the G-index developed by Gompers et al. (2003) ${ }^{11}$, the alternative institutional ownership proxies are total institutional ownership (TIO), blockholder ownership (Block1), and blockholder ownership tercile indicator variable (Block2), respectively. In columns (4)-(6), we repeat our analyses in columns (1)-(3) but replace the G-index by the E-index developed by Bebchuk et al. (2009) ${ }^{12}$.

Columns (1)-(6) of Table 4 show that the coefficients for the interaction term $M M I O_{1}$ $\times \Delta$ Cash holdings are all positive and statistically significant at the $1 \%$ or $5 \%$ level, which is consistent with the evidence in Table 2. After controlling for the corporate governance indexes and other institutional ownership measures simultaneously, the marginal value of cash increases from 10.6 cents to 22.1 cents for a firm with an average $M M I O_{1}$. A one

\footnotetext{
${ }^{11}$ Because the ISS stops reporting the G-index values after 2007, we follow Li and Li (2016) and extrapolate firms' G-index values after 2007, from their last available G-index values in the ISS.

${ }^{12}$ The entrenchment index, E-index, is composed of six anti-takeover provisions: staggered board, limits to shareholder bylaw amendments, limitations on amending the charter, poison pills, golden parachutes, and supermajority requirements to approve mergers and charter amendments (Bebchuk et al., 2009).
} 
standard deviation increase in $M M I O_{1}$ is associated with 16.2 cents to 33.7 cents higher marginal value of cash. Therefore, the positive effect of the most motivated monitoring institutional investors on the marginal value of cash remains robust, after controlling for the managerial entrenchment and other institutional ownership measures. In columns (1)(5), the coefficients of the interactions between $\Delta$ Cash holdings and corporate governance indexes are negative and statistically significant at the $5 \%$ or $10 \%$ level, which is consistent with Dittmar and Mahrt-Smith's (2007) finding that better firm corporate governance is associated with a higher marginal value of cash. Fich et al. (2015) identify that the motivated monitoring IO of M\&A targets is positively related to the deal completion probability, the likelihood of bid revision, and the deal premium, while the proxies of traditional institutional ownership in targets are not related to these deal outcomes. Consistent with Fich et al. (2015), we find that the coefficients of the interactions between $\Delta$ Cash holdings and traditional institutional ownership measures are not significantly positive, suggesting that the motivation of institutional monitoring is more likely related to the relative importance of a firm to institutional investors.

The analyses in Table 4 are based on a smaller sample than our main sample. We require firms to have anti-takeover provision data in the ISS and discard the observations with middle terciles of blockholder ownership in columns (3) and (6). Therefore, we remain cautious about over-interpreting and generalizing these results. However, the positive relation between the most motivated monitoring institutional investors and the marginal value of cash is even stronger in our restricted samples and after controlling for the governance indexes and traditional institutional ownership proxies. In our untabulated results, we find that the pairwise correlation between $M M I O_{1}$ and TIO is 0.38 and statistically significant, indicating that $M M I O_{1}$ and TIO are not highly correlated. In contrast, the pairwise correlation between $M M I O_{1}$ and Block 1 is -0.02 and statistically significant and the pairwise correlation between $M M I O_{1}$ and G-index (E-index) is $0.12(0.03)$ and statistically significant, suggesting that our motivated monitoring IO measure captures firm governance which may not be explained by these traditional corporate governance proxies. 


\subsection{Motivated Monitoring Institutional Investor Types}

It is possible that different types of institutional investors may have different incentives to monitor the firms in their portfolios. To ensure that the positive effect of the most motivated monitoring institutional investors on the marginal value of cash is not driven by a specific type of institution, we refine $M M I O_{1}$ by institution type and rerun Model (1). We adopt two popular classifications in the institutional investor literature. First, following Brickley et al. (1988), Almazan et al. (2005), and Chen et al. (2007), we divide $M M I O_{1}$ into $M M I O_{1, \text { Independent }}$ and $M M I O_{1, \text { Grey }}$, according to the institutional investors' potential business ties with the invested firm. Independent institutional investors include independent investment advisors, investment companies, and public pension funds. Grey institutional investors include banks, insurance companies, private pension funds, university endowments, and foundations. ${ }^{13}$ Second, we adopt Bushee (1998)'s classification and divide $M M I O_{1}$ into $M M I O_{1, \text { Transient }}$, $M M I O_{1, \text { Quasi-indexer }}$, and $M M I O_{1, \text { Dedicated }}$.

We replace $M M I O_{1}$ by the refined motivated monitoring IO in Model (1) and report the regression results in Table 5. The coefficients for the interaction $M M I_{1, I O T y p e} \times$ $\Delta$ Cash holdings are positive and statistically significant in columns (1)-(4). In the order of independent, grey, transient, and quasi-indexer, the marginal value of cash increases by 6.0 cents, 4.0 cents, 5.1 cents, and 4.0 cents, respectively, for a firm with an average $M M I_{1, \text { IOType }}$ A one standard deviation increase in these four $M M I_{1, \text { IOType }}$ is associated with 7.3 cents to 10.3 cents higher marginal value of cash. The coefficient of $M M I O_{1, \text { Dedicated }} \times \Delta$ Cash holdings is positive but not statistically significant at the $10 \%$ level. One possible explanation for this statistical insignificance is that the number of dedicated institutions is much less than the number of transient and quasi-indexer institutions according to Bushee's (1998) classification. Our results suggest that the positive effect of institutional investors' monitoring motivation on the marginal value of cash does not concentrate on a certain type of institution. Even grey and transient institutions, which

\footnotetext{
${ }^{13}$ After 1998, the institution type classification is not accurate in the Thomson Reuters s34 files. We follow Brian Bushee's institution type classification for institutional investors after 1998.
} 
are commonly believed to be less active monitors, have a positive role in monitoring the firms that are important to them.

\subsection{Institutional Ownership by Ten Decile Monitoring Motiva- tion}

In the previous analyses, we measured most motivated monitoring IO by $M M I O_{1}$, the ownership of institutional investors whose holding value in a firm was within the top decile stock group in their portfolios. We followed Fich et al. (2015) and chose the top decile in our definition. However, there is no reason to assume that institutional investors lack motivation to monitor firms in the rest of the nine decile groups. To examine the relation between institutional investors with different monitoring motivations and the marginal value of cash, we rerun Model (1) by interacting $\Delta$ Cash holdings with all ten decile $M M I O_{j}$ individually. We expect that the monitoring motivation of institutional investors should decrease gradually from $M M I O_{1}$ to $M M I O_{10}$, where $M M I O_{10}$ represents the ownership of institutional investors with the least monitoring motivation.

We report the results of ten decile $M M I O_{j}$ in Table 6. The coefficients of the interactions between $\triangle$ Cash holdings and $M M I O_{1}-M M I O_{2}$ are positive and statistically significant at the $1 \%$ level, indicating that institutional investors may have a high motivation to monitor the cash holdings of firms in the top two deciles of their portfolios. For $\mathrm{MMIO}_{3}-\mathrm{MMIO}_{5}$, the effect of these IO measures on the marginal value of cash becomes statistically insignificant. On the other side, the coefficients of the interactions between $\triangle$ Cash holdings and $M M I_{6}-M M I O_{10}$ are negative and statistically significant at the $1 \%$ or $5 \%$ level, suggesting that institutional investors may lack the motivation to monitor the cash holdings of a firm in the bottom five decile groups of their portfolios. We plot the value effect of an average $M M I O_{j}$ on the marginal value of cash and the $95 \%$ confidence intervals of the effect in Figure 2. The value effect of an average $M M I O_{j}$ on the marginal value of cash varies from positive 8.3 cents $\left(M M I O_{1}\right)$ to negative 4.9 cents 
$\left(M M I O_{8}\right)$. We observe an obvious decreasing trend for the value effect from $M M I O_{1}$ to $M M I O_{10}$. Combined, the results in Tables 2-6 support our prediction that motivated monitoring institutional investors increase the marginal value of corporate cash holdings and institutional investors do not allocate their monitoring attention evenly to every stock in their portfolios.

\section{Robustness Tests and Further Discussions}

In this section, we conduct a battery of robustness tests and discuss the effect of most motivated institutional investors on firms' accounting performance through monitoring their cash holdings.

\subsection{Endogeneity of Motivated Monitoring Institutional Owner- ship}

The previous literature on the relation between institutional investors and corporate activities has long recognized the difficulty of disentangling the effect of institutional investor monitoring and other unobserved firm characteristics. A similar challenge in our study is to ensure that we identify the effect of motivated monitoring institutional investors on the marginal value of cash and not the effect of confounding variables. It is possible that institutional investors have private information on their holding firms and choose to invest

more in those with a higher marginal value of cash. To address this potential endogeneity issue due to the unobserved confounding variables and investors' self-selection, we adopt the following three identifications: 2SLS, high-dimensional fixed effects, and the change in most motivated monitoring IO.

\subsubsection{Two-stage least squares}

Following recent studies on firm switching between the Russell 1000 and 2000 indexes, we adopt an IV approach similar to Fich et al. (2015), Crane et al. (2016), and Schmidt and 
Fahlenbrach (2016). Russell Investments reconstitute the Russell 1000 and 2000 indexes in June every year. In terms of the market capitalization, the largest 1,000 firms are included in the Russell 1000 index and the subsequent 2,000 firms are included in the Russell 2000 index. $^{14}$ When firm stocks switch between the two Russell indexes or are newly added in the indexes, the index tracking institutional ownership of these stocks will change exogenously. The portfolio adjustment of index tracking funds will also pose an exogenous shock on firm stocks that are not affected by the Russell index reconstitution. To satisfy the exclusion restriction, we choose the Russell switch indicator variables in year $t-1$ as our IVs so that firm excess returns over year $t$ are not correlated with these IVs.

In the first stage of our analysis, we estimate the following regression:

$$
\begin{aligned}
M M I O_{i, 1, t}= & \beta_{0}+\beta_{1} R 1 T R 2_{i, t-1}+\beta_{2} R 2 T R 1_{i, t-1}+\beta_{3} R 2 T N_{i, t-1}+\beta_{4} N T R 2_{i, t-1} \\
& +B * \text { Control variables } i, t+\epsilon_{i, t}
\end{aligned}
$$

where $R 1 T R 2_{i, t}\left(R 2 T R 1_{i, t}\right)$ is an indicator variable equal to 1 if firm $i$ switches from the Russell 1000 (2000) index to the Russell 2000 (1000) index in year $t$, and $R 2 T N_{i, t}$ $\left(N T R 2_{i, t}\right)$ is an indicator variable equal to 1 if firm $i$ enters (leaves) the Russell 2000 index. The predicted $M M I O_{1}$ from Model (4) enters as an explanatory variable into our second stage regression of Model (1). The control variables in Model (4) are the same as those included in Model (1). ${ }^{15}$

In Panel A of Table 7, we replicate our main results from Table 2 using the Russell index reconstitution as IVs for most motivated monitoring IO. Columns (1)-(3) report the results of the first stage regressions. The coefficients of IVs are statistically significant in the first stage regression, suggesting that our Russell index switch indicators satisfy the relevance condition as IVs. The results reported in columns (4)-(6) show that the coefficients of the interaction terms between the predicted motivated monitoring IO and

\footnotetext{
${ }^{14}$ Please refer to www.ftserussell.com/research-insights/russell-reconstitution for the detailed explanations of the Russell index reconstitution.

${ }^{15}$ In our untabulated tests, we follow Appel et al. (2016a) and add $\ln$ (firm market capitalization) and $(\ln (\text { firm market capitalization }))^{2}$ as the control variables in our 2SLS regressions. Firm market capitalizations are measured at the end of May. Our results remain qualitatively the same.
} 
$\Delta$ Cash holdings remain positive and statistically significant. In further robustness tests, we replicate our results from Table 3 using the IV identification and report the results in Panel B of Table 7. The effect of predicted most motivated monitoring IO on the marginal value of cash remains positive and statistically significant across three alternative definitions of the expected change in cash holdings.

\subsubsection{High-dimensional fixed effects}

The potential endogeneity associated with motivated monitoring institutional investors may be due to unobserved firm characteristics affecting both institutional investor monitoring motivation and the value of corporate cash holdings. Previous studies have documented many factors related to the value of corporate cash holdings. ${ }^{16}$ However, it is practically implausible to control for all of them in our empirical studies. We adopt the identification from Gormley and Matsa (2014) and use high-dimensional fixed effects to indirectly control for any unobserved or omitted firm characteristics. In columns (1) and (2) of Table 8, we estimate Model (1) and its extension by controlling for the firm and year fixed effects. In columns (3) and (4), we rerun these two regressions by controlling for the triple fixed effects of Firm $\times$ Year $\times$ Fama-French 48 industry. All the coefficients of $M M I O_{1} \times \Delta$ Cash holdings are positive and statistically significant at the $1 \%$ level. The marginal value of cash increases by 3.9 cents to 4.6 cents for a firm with an average $M M I O_{1}$. A one standard deviation increase in $M M I O_{1}$ is associated with 6.0 cents to 7.0 cents higher marginal value of cash. The positive effect of most motivated monitoring IO on the marginal value of cash remains both statistically and economically significant after controlling for unobserved firm characteristics.

\subsubsection{Change in motivated monitoring institutional ownership}

We use the level of IO as our main explanatory variable in the previous analyses. To further address the endogeneity due to the reverse causality concern that institutional

\footnotetext{
${ }^{16}$ We have reviewed some of them at the end of Section 1.
} 
investors choose to invest more in firms with a higher marginal value of cash, we conduct a semi-difference-in-difference test in which we replace $M M I O_{1}$ in Model (1) by the change in $M M I O_{1}$ from March to September year $t\left(\Delta^{\prime} M M I O_{1}\right) . \Delta^{\prime} M M I O_{1}$ may extract the impact of the changes in most motivated monitoring IO on the marginal value of cash. Our test results are reported in Table 9. The coefficients of $\Delta^{\prime} M M I O_{1} \times \Delta$ Cash holdings are all positive and statistically significant at the $1 \%$ level, suggesting that the increase in most motivated monitoring IO is positively related to the marginal value of cash. A one standard deviation increase in $\Delta^{\prime} M M I O_{1}(0.07)$ is associated with 10.1 cents to 11.4 cents increase in the marginal value of cash.

\subsection{Monitoring Motivation-weighted Institutional Ownership}

In section 3.5, we divide a firm's IO into ten groups and document a decreasing trend for the value effects of these ten $M M I O_{\mathrm{s}}$ on corporate cash holdings, from $M M I O_{1}$ to $M M I O_{10}$. Based on these findings, we construct a measure of general monitoring motivation-weighted IO, TMA (total monitoring attention), which includes all the ownership of a firm's institutional investors:

$$
T M A_{i}=\ln \left(1+\sum_{j=1}^{N} \omega_{i, j} * I O_{i, j} * 10,000\right)
$$

where $N$ is the total number of institutions investing in firm $i, \omega_{i, j}$ is the market value weight of firm $i$ 's stock in institution $j$ 's portfolio, and $I O_{i, j}$ is the ownership of institution $j$ in firm $i$. Because institutions' monitoring attention to a firm is positively related to the relative importance of the firm's stock in their portfolios, $\omega_{i, j}$ may represent institution $j$ 's motivation to monitor firm $i . I O_{i, j}$ may represent the monitoring effectiveness of institution $j$ in firm $i$. As the measure of general monitoring motivation-weighted IO, TMA $A_{i}$ takes account of both institutional investors' monitoring motivation and their voting power in firm $i$. We examine the effect of $T M A$ on the marginal value of cash in Table 10. Columns (1)-(2) report the OLS regression results and columns (3)-(4) report the results of the 
second stage regression in our 2SLS regressions. The coefficients of $T M A \times \Delta$ Cash holdings and $I V T M A \times \Delta$ Cash holdings are all positive and statistically significant at the $1 \%$ level, suggesting that firms with a greater $T M A$ attract a higher aggregated institutional investor monitoring attention. Column (2) indicates that the marginal value of cash increases by 10.1 cents for a firm with an average $T M A$ and that a one standard deviation increase in $T M A$ is associated with 6.4 cents increase in the marginal value of cash.

\subsection{Institutional Monitoring Across Three Cash Regimes}

Faulkender and Wang (2006) use firms' interest coverage and industry market-to-book ratio to classify three cash regimes: raising cash, distributing cash, and servicing debt. ${ }^{17}$ Across these three ex ante classified cash regimes, the value of one additional dollar cash varies considerably, with the highest value $\$ 1.16$ in the raising cash regime and the lowest value $\$ 0.45$ in the servicing debt regime. Our untabulated results show that $M M I O_{1}$ has a positive effect on the marginal value of cash across the three cash regimes defined by Faulkender and Wang (2006).

Halford et al. (2016) assume that stock prices can unbiasedly incorporate firms' actions in the future and use an ex post classification to group firms into the following three cash regimes. First, firms that issue equity and do not pay dividends in fiscal year $t$ are within the raising cash regime in that year. Second, firms that distribute cash to shareholders and do not issue equity in fiscal year $t$ are within the distributing cash regime in that year. Third, firms that have their market leverage ratios in the top decile distribution of firms in the beginning of fiscal year $t$, and do not raise or distribute cash over that year, are within the servicing debt regime in that year. ${ }^{18}$ More importantly, Halford et al. (2016) find that the two corporate governance measures examined in Dittmar and Mahrt-Smith (2007) do not have a significant effect on the marginal value of cash in any of

\footnotetext{
${ }^{17}$ Interest coverage is defined as the sum of cash holdings and earnings in the beginning of fiscal year $t$ divided by the interest expense over the same year.

${ }^{18}$ A firm may be classified into different cash regimes according to the classifications of Faulkender and Wang (2006) and Halford et al. (2016). It is not our paper's objective to compare these two classifications. We only check if our main results are robust to different cash regime classifications.
} 
these three cash regimes. We replicate our Model (1) with the IV identification in Halford et al.'s (2016) three cash regimes and report the results in Table 11. In the raising cash and distributing cash regimes, the coefficients of $M M I O_{1} \times \Delta$ Cash holdings are positive and statistically significant at the $1 \%$ level. In the servicing debt regime, the coefficient of $M M I O_{1} \times \Delta$ Cash holdings is positive but not statistically significant at the $10 \%$ level.

As argued in Halford et al. (2016), "the foundational theory is silent as to the regimes in which corporate governance should affect the marginal value of cash". Our empirical results suggest that stronger motivated monitoring IO is associated with a higher marginal value of cash for firms that are in the raising cash regime and distributing cash regime. For firms in the servicing debt regime, it is possible that debtholders have the main claims on the cash holdings and, therefore, equity holders may have less motivation to monitor these firms.

\subsection{Monitoring and Firm Operating Performance}

So far, our results show that motivated monitoring IO is positively related to the stock market valuation of corporate cash holding. It remains unknown whether firms actually benefit from the increase in the value of their cash holdings. For example, the marginal value of cash is higher for firms that are more financially constrained. In order to show that the increase in the marginal value of cash is actually the result of good corporate policy, we study the real outcomes of monitoring by motivated institutional investors. Cash is a firm's

most liquid asset, subject to the highest level of managerial discretion (Jensen, 1986). If institutional investors inhibit the agency cost of managerial discretion, we would expect to observe a positive relation between firms' cash holdings and operating performance when motivated monitoring IO is high.

We examine four Fama-French 48 industry-adjusted operating performance measures studied in Kim et al. (2014): return on assets, return on equity, net profit margin, and asset turnover. To address the endogeneity between most motivated monitoring IO and firm operating performance, we use the IV approach discussed in section 4.1.1. Table 12 
reports the estimation results. Consistent with our expectation, the coefficients of the interaction between predicted $M M I O_{1}$ and cash holdings are all positive and statistically significant in the second stage regressions.

\subsection{Motivated Monitoring Institutional Ownership and Firm Size}

For firms with larger market capitalization, it is more likely that their market value weights are ranked at the top of an institution's portfolio. One alternative explanation of our main results is that most motivated monitoring IO is positively associated with firm size. Gompers and Metrick (2001) find that institutional investors invest more in large firms and therefore stock returns are positively related to firm size. As a result, the positive effect of most motivated monitoring IO on the marginal value of cash documented in our paper may only indicate that cash is more valuable in larger firms. The correlation between $M M I O_{1}$ and firm size is 0.63 in our sample. We do not directly control for firm

size as an independent variable in Model (1), because the dependent variable is annual firm returns, adjusted by Fama-French 25 size and book-to-market portfolio returns. In our untabulated tests, we add Size and Size $\times \Delta$ Cash holdings as control variables in Model (1) and the coefficient of $M M I O_{1} \times \Delta$ Cash holdings remains positive and statistically significant at the $1 \%$ level. The coefficient of Size is not statistically significant at the $10 \%$ level and the coefficient of Size $\times \Delta$ Cash holdings is negative and statistically significant at the $1 \%$ level. Our results, reported in Table 6, are also robust after controlling for Size and Size $\times \Delta$ Cash holdings. These results suggest that the positive effect of $M M I O_{1}$ on the marginal value of cash does not arise solely from the firm size effect. 


\subsection{Motivated Monitoring Institutional Investors and the Value of Excess Cash}

In our previous empirical analyses, we adopt Faulkender and Wang's (2006) specification and estimate the change in firm market value associated with a change of one dollar in cash holdings. Several previous studies on the value of cash employ another framework, initiated by Fama and French (1998), and estimate the value of firm excess cash based on a price-level regression (e.g., Dittmar and Mahrt-Smith, 2007; Kyröläinen et al., 2013; Gao and Jia, 2016). Dittmar and Mahrt-Smith (2007) argue that excess cash might be more relevant to the agency problem than cash holdings. ${ }^{19}$ The dependent variable in the price-level regression is the market value of assets, normalized by the book value of net assets, similar to the market-to-book ratio. We use the IV approach discussed in section 4.1.1 to estimate the predicted most motivated monitoring IO because the market-to-book ratio is a standard proxy for firm growth opportunities and might be endogenously correlated with IO. Then we add both the predicted most motivated monitoring IO and the interaction term of it and excess cash in the price-level regression. Our untabulated results, based on the price-level regression, are consistent with our main results. Greater motivated monitoring IO is associated with a higher value of excess cash.

\subsection{Changes in US Public Firms Over Time}

It is well known that the US stock market has become more institutionalized during the last 40 years (Gompers and Metrick, 2001; Zeng, 2016). Over the same time period, US public firms also experienced substantial changes in terms of their firm policies and characteristics. Kahle and Stulz (2017) find that there are fewer US public firms and on average they are older, less profitable, invest more in $\mathrm{R} \& \mathrm{D}$, hold more intangible assets and cash, and have more payouts to shareholders. Furthermore, Bates et al. (2017) document a positive time trend in the value of corporate cash holdings from 1980 to 2009. Given

\footnotetext{
${ }^{19}$ Please refer to Dittmar and Mahrt-Smith (2007) for the detailed discussion of the price-level regression.
} 
these two recent studies, one potential concern is that we observe the positive relation between motivated monitoring IO and the marginal value of cash because both have a positive time trend over our sample period. It is also possible that the positive relation we document is affected by the changes in firm policies and characteristics over time. In our empirical analyses, we have controlled for the year fixed effects and established the causality by documenting that the changes in motivated monitoring IO lead to an increase in the marginal value of cash. In this section, we examine whether our main results are robust to the changes in US public firms.

To allow for a more nuanced interpretation of the coefficients, we conduct sub-sample analyses and report the results in Table 13. We employ the same 2SLS regression model as the one used in Panel A of Table 7. For brevity, we only report the second stage regression results. We first examine whether the positive relation between motivated monitoring IO and the marginal value of cash varies over time. We split our sample into 1995-2004 and 2005-2015. Columns (1)-(2) show that motivated monitoring IO has a significantly positive effect on the marginal value of cash over both time periods. Different from our results, Bates et al. (2017) find that institutional block holdings only have a significantly positive effect on the marginal value of cash in the 1990s, but not in the 1980s or the 2000s. This difference further supports the importance of considering the monitoring motivation of institutional investors in the future corporate governance studies.

Next, we divide our sample into two sub-samples based on the medians of firm policies and characteristics that have gradually changed over time according to Kahle and Stulz (2017): cash holdings, firm age, R\&D expenses, intangible assets, and profitability. ${ }^{20}$ The high (low) sub-samples include firm-years with above(below)-annual-median firm-level variables. Columns (3)-(12) of Table 13 represent the results of our sub-sample analyses. The estimated coefficients of $I V M I O_{1} \times \Delta$ Cash holdings remain positive and statistically significant over both sub-samples for all five firm policies/characteristics. Because we find

\footnotetext{
${ }^{20}$ Kahle and Stulz (2017) also indicate that US firms pay out more to shareholders. In Section 4.3, we have shown that motivated monitoring IO has a positive effect on the marginal value of cash when firms are in the distributing cash regime.
} 
robust evidence that motivated monitoring IO is positively associated with the marginal value of cash in both high and low sub-samples, it is unlikely that our main result is driven by the changes in firms over our sample period.

Overall, our findings indicate that the positive impact of motivated monitoring IO on the marginal value of cash is persistent over time and robust after taking into consideration of the changes in US public firms.

\section{Conclusions}

Firms may hold cash because they are uncertain about their immediate future environment, or because they want to retain the flexibility to exploit investment opportunities that may arise unexpectedly. The retention of cash might therefore be expected to be valued positively if investors were confident in the firms' managers. However, cash reserves offer managers the scope to exploit their agency position and might, therefore, be value reducing when seen by sceptical investors. In curbing agency discretion, investors need to monitor managerial decisions and, therefore, it is natural to examine those investors who have the greatest motivation to carry out the monitoring activities. Institutional investors, because of the size of their holdings, are likely to be willing to spend time and resources in monitoring the actions of boards controlling the firms in which they hold stock. However, institutions' monitoring attention is in limited supply and, therefore, it seems reasonable that even large institutional investors will allocate their monitoring activities to those firms in which they invest most of their money.

In this paper, we follow Fich et al. (2015) to identify the motivated monitoring institutional investors and have analyzed motivated monitors using the marginal value of corporate cash holdings as an empirical setting. Clearly the market impounds the past and expected cash holdings in observed prices, so the task is to examine the stock price reactions to unexpected changes in cash holdings. For those firms in which there is greater

motivated monitoring institutional ownership, the marginal value of cash is indeed found 
to be higher - thereby lending support to the argument that institutional investors contribute to the efficiency of corporate governance through their monitoring activities. This is further strengthened by the finding that the accounting-based performance measures are also positively related to the institution monitoring firm's cash holdings. We also find that the changes in valuation we ascribe to the investors identified as having the strongest motivation to monitor, are not subsumed in other suggested indicators of corporate governance such as: total institutional ownership, blockholdings, or corporate governance indexes. The effect we find is not restricted to any specific type of institutions and our findings remain robust to including other alternative explanatory variables. Our classifications of institution monitoring motivation provide a rational direction of positive valuation effects - investors who hold less important stakes in firms do not appear to be associated with the increased valuations that are found in firms with more motivated investors.

The general conclusion of our findings is that institutional investors' monitoring attention concentrates on the firms whose market value weights are among the top of their portfolios. Motivated monitoring institutional investors appear to perform a valuable role through their monitoring activities in ensuring that corporate cash holdings are not wasted and managerial decisions are, thereby, more appropriately aligned with shareholders' interests.

\section{Highlights}

- Institutions do not evenly distribute their monitoring attention to their holding firms.

- Institutions' monitoring attention to a firm drops with the firm's weight in their portfolios.

- Marginal value of cash is positively related to motivated monitoring institutional ownership. 


\section{Appendix A}

\section{Table A1. Variable definitions}

This table provides variable definitions and corresponding data sources. CRSP refers to the Centre for Research in Security Prices, ISS refers to the Institutional Shareholder Services (formerly RiskMetrics), s34 files refer to the Thomson Reuters 13F Database, Bushee's website refers to http://acct.wharton.upenn.edu/faculty/bushee/IIclass.html, and FF refers to

Kenneth French's website http://mba.tuck.dartmouth.edu/pages/faculty/ken.french/data library.html\#Benchmarks.

\begin{tabular}{|c|c|c|}
\hline Variable & Definition & Source \\
\hline$M M I O_{1}-M M I O_{10}$ & $\begin{array}{l}M M I O_{i} \text { is the ownership of institutional investors whose } \\
\text { holding value in a firm is within the range of the top } \\
10(i-1) \% \text { and } 10 i \% \text { portfolio stock holdings in September } \\
\text { of year } t \text { (Fich et al., 2015). }\end{array}$ & s34 files \\
\hline$P M M I_{1}$ & $\begin{array}{l}\text { Ratio of the number of most motivated monitoring } \\
\text { investors to the total number of institutional investors } \\
\text { (Fich et al., 2015). }\end{array}$ & s34 files \\
\hline$N M M I_{1}$ & $\begin{array}{l}\text { Number of the most motivated monitoring institutional } \\
\text { investors (Fich et al., 2015). }\end{array}$ & s34 files \\
\hline TIO & Total institutional ownership. & s34 files \\
\hline$M M I O_{1, \text { Independent }}$ & Ownership of most motivated monitoring investors who & s34 files \& \\
\hline$M M I O_{1, \text { Grey }}$ & $\begin{array}{l}\text { are classified as independent ones (Chen et al., 2007). } \\
\text { Ownership of most motivated monitoring investors who }\end{array}$ & $\begin{array}{l}\text { Bushee's website } \\
\text { s34 files \& }\end{array}$ \\
\hline$M M I O_{1, \text { Transient }}$ & $\begin{array}{l}\text { are classified as grey ones (Chen et al., 2007). } \\
\text { Ownership of most motivated monitoring investors who } \\
\text { are classified as transient ones (Bushee, 2001). }\end{array}$ & $\begin{array}{l}\text { Bushee's website } \\
\text { s34 files \& } \\
\text { Bushee's website }\end{array}$ \\
\hline$M M I O_{1, Q u a s i-i n d e x e r}$ & $\begin{array}{l}\text { Ownership of most motivated monitoring investors who } \\
\text { are classified as quasi-indexer ones (Bushee, 2001). }\end{array}$ & $\begin{array}{l}\text { s34 files \& } \\
\text { Bushee's website }\end{array}$ \\
\hline$M M I O_{1, \text { Dedicated }}$ & $\begin{array}{l}\text { Ownership of most motivated monitoring investors who } \\
\text { are classified as dedicated ones (Bushee, 2001). }\end{array}$ & $\begin{array}{l}\text { s34 files \& } \\
\text { Bushee's website }\end{array}$ \\
\hline$\Delta^{\prime} M M I O_{1}$ & $\begin{array}{l}\text { Change in } M M I O_{1} \text { from March to September of year } t \\
\text { (Fich et al., 2015). }\end{array}$ & s34 files \\
\hline$T M A$ & Monitoring motivation-weighted institutional ownership. & s34 files \\
\hline$r_{i}-R_{i}^{B}$ & $\begin{array}{l}\text { Excess stock returns with the benchmark portfolios defined } \\
\text { as Fama-French } 25 \text { portfolios formed on size and } \\
\text { book-to-market (Faulkender and Wang, 2006). }\end{array}$ & $\begin{array}{l}\text { CRSP, } \\
\text { Compustat, and } \\
\text { FF }\end{array}$ \\
\hline$M V$ & $\begin{array}{l}\text { Market value of equity, defined as the number of shares } \\
\text { outstanding (CSHPRI) multiplied by stock price } \\
\text { (PRCC_F) (Faulkender and Wang, 2006). }\end{array}$ & Compustat \\
\hline Cash holdings & $\begin{array}{l}\text { Cash plus marketable securities (CHE) normalized by } M V \\
\text { (Faulkender and Wang, 2006). }\end{array}$ & Compustat \\
\hline
\end{tabular}

Continued on next page 
Table A1 - continued from previous page

\begin{tabular}{|c|c|c|}
\hline Variable & Definition & Source \\
\hline$\Delta$ Cash holdings & $\begin{array}{l}\text { Change in cash holdings from fiscal year } t-1 \text { to year } t \text {, } \\
\text { normalized by } M V \text { at the start of fiscal year } t \text { (Faulkender } \\
\text { and Wang, 2006). }\end{array}$ & Compustat \\
\hline$\Delta$ Earnings & $\begin{array}{l}\text { Change in earnings from fiscal year } t-1 \text { to year } t \\
\text { normalized by } M V \text { at the start of fiscal year } t \text {. Earnings } \\
\text { are calculated as earnings before extraordinary items (IB) } \\
\text { plus interest (XINT), deferred tax credits (TXDI), and } \\
\text { investment tax credits (ITCI) (Faulkender and Wang, } \\
2006 \text { ). }\end{array}$ & Compustat \\
\hline$\Delta$ Net assets & $\begin{array}{l}\text { Change in net assets from fiscal year } t-1 \text { to year } t \text {, } \\
\text { normalized by } M V \text { at the start of fiscal year } t \text {. Net assets } \\
\text { are calculated as total assets (AT) minus cash holdings } \\
\text { (CHE) (Faulkender and Wang, 2006). }\end{array}$ & Compustat \\
\hline$\Delta R \& D$ & $\begin{array}{l}\text { Change in R\&D expenditure (XRD) from fiscal year } t-1 \\
\text { to year } t \text {, normalized by } M V \text { at the start of fiscal year } t \\
\text { (Faulkender and Wang, 2006). }\end{array}$ & Compustat \\
\hline$\Delta$ Interest expenses & $\begin{array}{l}\text { Change in interest expenses (XINT) from fiscal year } t-1 \\
\text { to year } t \text {, normalized by } M V \text { at the start of fiscal year } t \\
\text { (Faulkender and Wang, 2006). }\end{array}$ & Compustat \\
\hline$\Delta$ Dividends & $\begin{array}{l}\text { Change in total common share dividends (DVC) from } \\
\text { fiscal year } t-1 \text { to year } t \text {, normalized by } M V \text { at the start } \\
\text { of fiscal year } t \text { (Faulkender and Wang, 2006). }\end{array}$ & Compustat \\
\hline Leverage & $\begin{array}{l}\text { Calculated as total debt (DLC+DLTT) divided by the } \\
\text { sum of total debt and } M V \text { (Faulkender and Wang, 2006). }\end{array}$ & Compustat \\
\hline Net financing & $\begin{array}{l}\text { Net financing proceeds are defined as equity issuance } \\
\text { (SSTK) minus repurchases (PRSTKC), plus debt issuance } \\
\text { (DLTIS) minus debt redemption (DLTR) (Faulkender and } \\
\text { Wang, 2006). }\end{array}$ & Compustat \\
\hline$R 1 T R 2$ & $\begin{array}{l}\text { Indicator takes one when firms switch from the Russell } \\
1000 \text { to the Russell } 2000 \text { index due to the relative decrease } \\
\text { in market value, zero otherwise (Fich et al., 2015). }\end{array}$ & Bloomberg \\
\hline$R 2 T R 1$ & $\begin{array}{l}\text { Indicator takes one when firms switch from the Russell } \\
2000 \text { to the Russell } 1000 \text { index due to the relative increase } \\
\text { in market value, zero otherwise (Fich et al., 2015). }\end{array}$ & Bloomberg \\
\hline$R 2 T N$ & $\begin{array}{l}\text { Indicator takes one when firms drop out of the Russell } \\
2000 \text { index due to the relative decrease in market value, } \\
\text { zero otherwise (Fich et al., 2015). }\end{array}$ & Bloomberg \\
\hline$N T R 2$ & $\begin{array}{l}\text { Indicator takes one when firms are newly added into the } \\
\text { Russell } 2000 \text { index due to the relative increase in market } \\
\text { value, zero otherwise (Fich et al., 2015). }\end{array}$ & Bloomberg \\
\hline
\end{tabular}

Continued on next page 
Table A1 - continued from previous page

\begin{tabular}{|c|c|c|}
\hline Variable & Definition & Source \\
\hline$R O A$ & $\begin{array}{l}\text { Fama-French } 48 \text { industry-adjusted return on asset, } \\
\text { calculated as income before extraordinary items (IB) } \\
\text { divided by average book value of assets (AT) between } \\
\text { fiscal year } t \text { and } t-1 \text { (Kim et al., 2014). }\end{array}$ & Compustat \\
\hline$R O E$ & $\begin{array}{l}\text { Fama-French } 48 \text { industry-adjusted return on equity, } \\
\text { calculated as income before extraordinary items (IB) net } \\
\text { of preferred stock dividend (DVP) divided by average book } \\
\text { value of equity (CEQ) between fiscal year } t \text { and } t-1 \text { (Kim } \\
\text { et al., 2014). }\end{array}$ & Compustat \\
\hline Nmargin & $\begin{array}{l}\text { Fama-French } 48 \text { industry-adjusted net profit margin, } \\
\text { calculated as income before extraordinary items (IB) } \\
\text { divided by net sales (SALE) (Kim et al., 2014). }\end{array}$ & Compustat \\
\hline AssetTO & $\begin{array}{l}\text { Fama-French } 48 \text { industry adjusted asset turnover, } \\
\text { calculated as net sales (SALE) divided by average book } \\
\text { value of assets (AT) (Kim et al., 2014). }\end{array}$ & Compustat \\
\hline Cash/Total assets & $\begin{array}{l}\text { Cash plus marketable securities (CHE) normalized by total } \\
\text { assets (AT). }\end{array}$ & Compustat \\
\hline Age & $\begin{array}{l}\text { Firm age, calculated as } \operatorname{Ln}(1+\text { Number of years since the } \\
\text { first time the firm appeared in Compustat) (Kim et al., } \\
\text { 2014). }\end{array}$ & Compustat \\
\hline Size & $\begin{array}{l}\text { Firm size, calculated as } \operatorname{Ln}(\text { book value of asset }(\mathrm{AT})) \\
\text { (Kim et al., 2014). }\end{array}$ & Compustat \\
\hline$M T B$ & $\begin{array}{l}\text { Market-to-book ratio, calculated as market value of assets } \\
(M V+\text { total debt) divided by book value of assets (AT) } \\
\text { (Kim et al., 2014). }\end{array}$ & Compustat \\
\hline Tangibility & $\begin{array}{l}\text { Asset tangibility, calculated as property plant and } \\
\text { equipment (PPENT) divided by total assets (AT) (Kim } \\
\text { et al., 2014). }\end{array}$ & Compustat \\
\hline Capital expenditure & $\begin{array}{l}\text { Capital expenditure (CAPEX) normalized by total assets } \\
\text { (AT). }\end{array}$ & Compustat \\
\hline$G$-index & $\begin{array}{l}\text { Corporate governance index composed of twenty-four } \\
\text { provisions on investor rights and takeover protections } \\
\text { applied to the company (Gompers et al., 2003). }\end{array}$ & ISS \\
\hline E-index & $\begin{array}{l}\text { Entrenchment index composed of the six most important } \\
\text { provisions in G-index (Bebchuk et al., 2009). }\end{array}$ & ISS \\
\hline Block1 & $\begin{array}{l}\text { Aggregate ownership of all institutional investors whose } \\
\text { ownership exceeds } 5 \% \text { of common shares outstanding of a } \\
\text { firm. }\end{array}$ & s34 files \\
\hline Block2 & $\begin{array}{l}\text { Blockholder ownership indicator variable which is equal to } \\
1 \text { if a firm is among the top tercile blockholder ownership } \\
\text { distribution and zero if a firm is among the bottom tercile } \\
\text { blockholder ownership distribution (Dittmar and } \\
\text { Mahrt-Smith, 2007). }\end{array}$ & s34 files \\
\hline
\end{tabular}




\section{References}

Alimov, A., 2014. Product market competition and the value of corporate cash: Evidence from trade liberalization. Journal of Corporate Finance 25, 122-139.

Almazan, A., Hartzell, J. C., Starks, L. T., 2005. Active institutional shareholders and costs of monitoring: Evidence from executive compensation. Financial Management 34, $5-34$.

Almeida, H., Campello, M., Weisbach, M. S., 2004. The cash flow sensitivity of cash. Journal of Finance 59, 1777-1804.

Appel, I. R., Gormley, T. A., Keim, D. B., 2016a. Passive investors, not passive owners. Journal of Financial Economics 121, 111-141.

Appel, I. R., Gormley, T. A., Keim, D. B., 2016b. Standing on the shoulders of giants: The effect of passive investors on activism. Tech. rep., Working Paper, National Bureau of Economic Research.

Bates, T. W., Chang, C. H., Chi, J. D., 2017. Why has the value of cash increased over time? Journal of Financial and Quantitative Analysis, Forthcoming.

Bates, T. W., Kahle, K. M., Stulz, R. M., 2009. Why do US firms hold so much more cash than they used to? Journal of Finance 64, 1985-2021.

Bebchuk, L. A., Cohen, A., Ferrell, A., 2009. What matters in corporate governance? Review of Financial Studies 22, 783-827.

Brickley, J. A., Lease, R. C., Clifford W. Smith, J., 1988. Ownership structure and voting on antitakeover amendments. Journal of Financial Economics 20, 267-291.

Bushee, B. J., 1998. The influence of institutional investors on myopic R\&D investment behavior. The Accounting Review 73, 305-333.

Bushee, B. J., 2001. Do institutional investors prefer near-term earnings over long-run value? Contemporary Accounting Research 18, 207-246.

Cella, C., Ellul, A., Giannetti, M., 2013. Investors' horizons and the amplification of market shocks. Review of Financial Studies 26, 1607-1648.

Chen, X., Harford, J., Li, K., 2007. Monitoring: Which institutions matter? Journal of Financial Economics 86, 279-305.

Crane, A. D., Michenaud, S., Weston, J. P., 2016. The effect of institutional ownership on payout policy: Evidence from index thresholds. Review of Financial Studies hhw012, $1-32$. 
Cremers, K. M., Petajisto, A., 2009. How active is your fund manager? A new measure that predicts performance. Review of Financial Studies 22, 3329-3365.

Cronqvist, H., Fahlenbrach, R., 2009. Large shareholders and corporate policies. Review of Financial Studies 22, 3941-3976.

Denis, D. J., Sibilkov, V., 2009. Financial constraints, investment, and the value of cash holdings. Review of Financial Studies 23, 247-269.

Dittmar, A., Mahrt-Smith, J., 2007. Corporate governance and the value of cash holdings. Journal of Financial Economics 83, 599-634.

Drobetz, W., Grüninger, M. C., Hirschvogl, S., 2010. Information asymmetry and the value of cash. Journal of Banking and Finance 34, 2168-2184.

Duchin, R., 2010. Cash holdings and corporate diversification. Journal of Finance 65, 955992.

Edmans, A., Holderness, C. G., 2016. Blockholders: A survey of theory and evidence. Working Paper, Available at SSRN 2820976.

Fama, E. F., 1970. Efficient capital markets: A review of theory and empirical work. Journal of Finance 25, 383-417.

Fama, E. F., French, K. R., 1993. Common risk factors in the returns on stocks and bonds. Journal of Financial Economics 33, 3-56.

Fama, E. F., French, K. R., 1998. Taxes, financing decisions, and firm value. Journal of Finance 53, 819-843.

Faulkender, M., Wang, R., 2006. Corporate financial policy and the value of cash. Journal of Finance 61, 1957-1990.

Fich, E. M., Harford, J., Tran, A. L., 2015. Motivated monitors: The importance of institutional investors' portfolio weights. Journal of Financial Economics 118, 21-48.

Fich, E. M., Harford, J., Yore, A. S., 2016. The effect of takeover protection on the value of cash: Evidence from a natural experiment. Available at SSRN 2748086.

Gao, X., Jia, Y., 2016. Internal control over financial reporting and the safeguarding of corporate resources: Evidence from the value of cash holdings. Contemporary Accounting Research 33, 783-814.

Gompers, P. A., Ishii, J. L., Metrick, A., 2003. Corporate governance and equity prices. Quarterly Journal of Economics 118, 107-155.

Gompers, P. A., Metrick, A., 2001. Institutional investors and equity prices. Quarterly Journal of Economics 116, 229-259.

Gormley, T. A., Matsa, D. A., 2014. Common errors: How to (and not to) control for unobserved heterogeneity. Review of Financial Studies 27, 617-661. 
Halford, J. T., McConnell, J. J., Sibilkov, V., Zaiats, N. S., 2016. Cash regimes and the marginal value of cash. Working Paper, Available at SSRN 2761699.

Harford, J., Klasa, S., Maxwell, W. F., 2014. Refinancing risk and cash holdings. Journal of Finance 69, 975-1012.

Harford, J., Mansi, S. A., Maxwell, W. F., 2008. Corporate governance and firm cash holdings in the US. Journal of Financial Economics 87, 535-555.

Haushalter, D., Klasa, S., Maxwell, W. F., 2007. The influence of product market dynamics on a firm's cash holdings and hedging behavior. Journal of Financial Economics 84, 797825 .

Jensen, M. C., 1986. Agency costs of free cash flow, corporate finance, and takeovers. The American Economic Review 76, 323-329.

Kacperczyk, M., Van Nieuwerburgh, S., Veldkamp, L., 2016. A rational theory of mutual funds' attention allocation. Econometrica 84, 571-626.

Kahle, K., Stulz, R. M., 2017. Is the US public corporation in trouble? Journal of Economic Perspectives 31, 67-88.

Kempf, E., Manconi, A., Spalt, O. G., 2017. Distracted shareholders and corporate actions. Review of Financial Studies 30, 1660-1695.

Kim, K., Mauldin, E., Patro, S., 2014. Outside directors and board advising and monitoring performance. Journal of Accounting and Economics 57, 110-131.

Kyröläinen, P., Tan, I., Karjalainen, P., 2013. How creditor rights affect the value of cash: A cross-country study. Journal of Corporate Finance 22, 278-298.

Li, D., Li, E. X., 2016. Corporate governance and costs of equity: Theory and evidence. Management Science, Forthcoming.

Liu, C. Y., Low, A., Masulis, R., Zhang, L., 2016. Monitoring the monitor: Distracted institutional investors and board governance. Working Paper.

Louis, H., Sun, A. X., Urcan, O., 2012. Value of cash holdings and accounting conservatism. Contemporary Accounting Research 29, 1249-1271.

Schmidt, C., Fahlenbrach, R., 2016. Do exogenous changes in passive institutional ownership affect corporate governance and firm value? Journal of Financial Economics, Forthcoming.

Sims, C. A., 2003. Implications of rational inattention. Journal of Monetary Economics 50, 665-690.

Tong, Z., 2011. Firm diversification and the value of corporate cash holdings. Journal of Corporate Finance 17, 741-758.

Zeng, Y., 2016. Institutional investors: Arbitrageurs or rational trend chasers. International Review of Financial Analysis 45, 240-262. 


\section{Figure 1. US corporate cash holdings}

This figure plots the total cash holdings and cash to total assets ratios of US firms in our sample, which consists of all non-financial and non-utility firm-year observations for the period 1995-2015. All firms are covered by the CRSP/Compustat Merged dataset and listed on NYSE, NASDAQ, and AMEX. The bar charts represent total cash holdings, the sum of cash and marketable securities, in nominal and real terms. The line plot represents the ratios of total cash holdings to total assets.

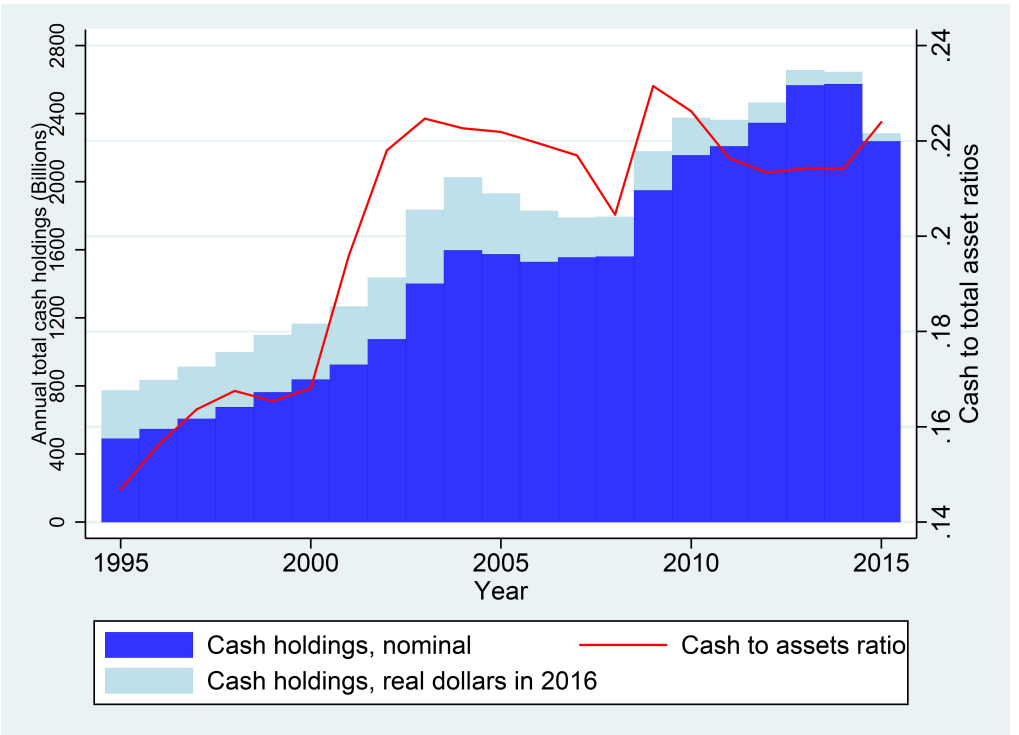

Figure 2. The economic effect of average $M M I O_{j}$ on the marginal value of cash

This figure plots the economic effect of $M M I O_{j}$ on the marginal value of cash, for $j$ from 1 to 10. The solid line plot represents the economic effect of an average $M M I O_{j}$ on the marginal value of cash. The dashed lines and the shaded area represent the $95 \%$ confidence intervals of the economic effect. This figure is based on the estimated coefficients of $M M I O_{j} \times \Delta$ Cash holdings reported in Table 6 .

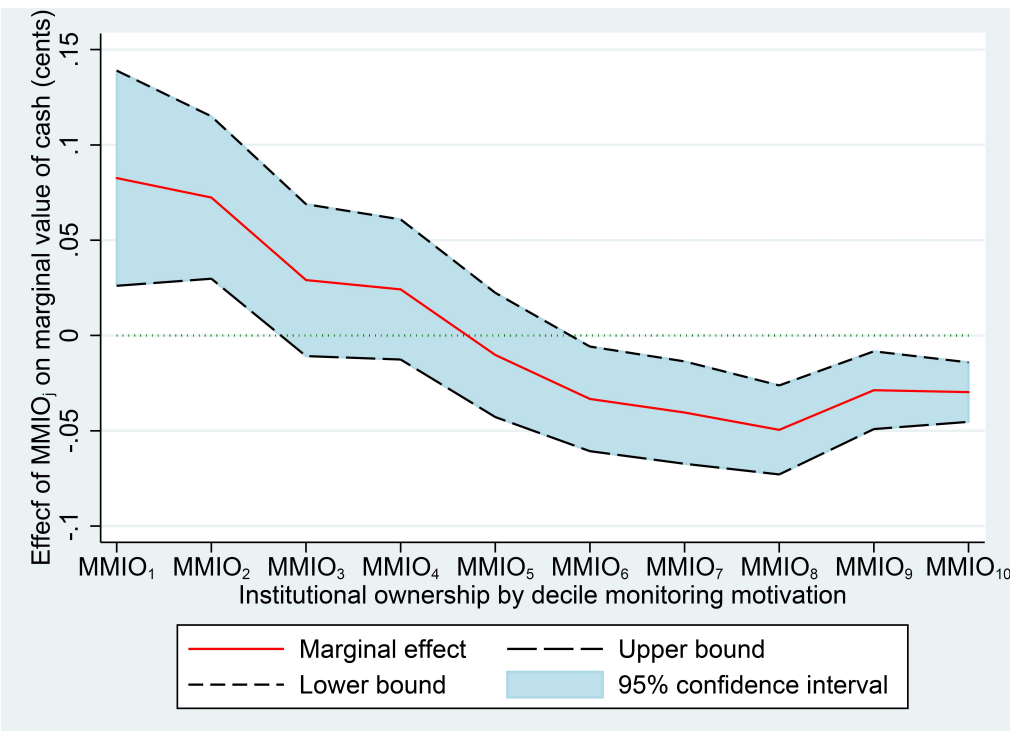




\section{Table 1. Summary statistics}

This table reports summary statistics of all variables used in our empirical tests. The sample consists of 67,404 firm-year observations of US firms over the sample period 19952015 with required data for our regressions. The number of observations, mean, standard deviation, minimum, 25th percentile, median, 75th percentile, and maximum are reported from left to right, in sequence for each variable. Detailed definitions of all variables are described in Appendix A.

\begin{tabular}{|c|c|c|c|c|c|c|c|c|}
\hline Variable & Obs. & Mean & S.D. & Min & p25 & Median & p75 & Max \\
\hline$M M I O_{1}$ & 67,404 & 0.106 & 0.162 & 0.000 & 0.000 & 0.015 & 0.155 & 1.000 \\
\hline $\mathrm{MMIO}_{2}$ & 67,404 & 0.086 & 0.107 & 0.000 & 0.000 & 0.045 & 0.141 & 0.997 \\
\hline $\mathrm{MMIO}_{3}$ & 67,404 & 0.071 & 0.087 & 0.000 & 0.000 & 0.041 & 0.112 & 0.996 \\
\hline $\mathrm{MMIO}_{4}$ & 67,404 & 0.058 & 0.072 & 0.000 & 0.000 & 0.033 & 0.087 & 0.970 \\
\hline$M M I O_{5}$ & 67,404 & 0.047 & 0.061 & 0.000 & 0.001 & 0.026 & 0.068 & 0.996 \\
\hline$M M I O_{6}$ & 67,404 & 0.038 & 0.051 & 0.000 & 0.003 & 0.020 & 0.053 & 0.994 \\
\hline $\mathrm{MMIO}_{7}$ & 67,404 & 0.029 & 0.041 & 0.000 & 0.003 & 0.014 & 0.038 & 0.944 \\
\hline$M M I O_{8}$ & 67,404 & 0.021 & 0.033 & 0.000 & 0.003 & 0.010 & 0.026 & 0.933 \\
\hline$M M I O_{9}$ & 67,404 & 0.014 & 0.025 & 0.000 & 0.002 & 0.006 & 0.017 & 0.977 \\
\hline$M M I O_{10}$ & 67,404 & 0.008 & 0.017 & 0.000 & 0.001 & 0.003 & 0.008 & 0.796 \\
\hline$P M M I_{1}$ & 67,404 & 0.035 & 0.060 & 0.000 & 0.000 & 0.011 & 0.046 & 1.000 \\
\hline$N M M I_{1}$ & 67,404 & 11.519 & 45.548 & 0.000 & 0.000 & 1.000 & 5.000 & 1100.000 \\
\hline $\operatorname{Ln}\left(1+N M M I_{1}\right)$ & 67,404 & 1.059 & 1.361 & 0.000 & 0.000 & 0.693 & 1.792 & 6.965 \\
\hline TIO & 67,404 & 0.476 & 0.305 & 0.000 & 0.193 & 0.490 & 0.739 & 1.000 \\
\hline$M M I O_{1, \text { Independent }}$ & 67,404 & 0.078 & 0.119 & 0.000 & 0.000 & 0.005 & 0.120 & 1.000 \\
\hline$M M I O_{1, \text { Grey }}$ & 67,404 & 0.028 & 0.065 & 0.000 & 0.000 & 0.000 & 0.016 & 0.993 \\
\hline$M M I O_{1, \text { Transient }}$ & 67,404 & 0.027 & 0.054 & 0.000 & 0.000 & 0.000 & 0.034 & 0.995 \\
\hline$M M I O_{1}$ Quasi-indexer & 67,404 & 0.065 & 0.117 & 0.000 & 0.000 & 0.000 & 0.083 & 0.998 \\
\hline$M M I O_{1, \text { Dedicated }}$ & 67,404 & 0.012 & 0.046 & 0.000 & 0.000 & 0.000 & 0.000 & 1.000 \\
\hline$\Delta^{\prime} M M I O_{1}$ & 67,404 & -0.001 & 0.070 & -0.980 & -0.007 & 0.000 & 0.006 & 1.000 \\
\hline$T M A$ & 67,404 & 2.590 & 1.638 & 0.000 & 1.170 & 2.889 & 3.816 & 9.086 \\
\hline$r_{i}-R_{i}^{B}$ & 67,404 & -0.001 & 0.600 & -1.021 & -0.355 & -0.090 & 0.204 & 2.631 \\
\hline Cash holdings $_{t-1}$ & 67,404 & 0.184 & 0.242 & 0.001 & 0.035 & 0.100 & 0.231 & 1.425 \\
\hline$\Delta$ Cash holdings & 67,404 & 0.006 & 0.137 & -0.503 & -0.032 & 0.001 & 0.036 & 0.633 \\
\hline$\Delta$ Earnings & 67,404 & 0.016 & 0.216 & -0.765 & -0.031 & 0.005 & 0.040 & 1.102 \\
\hline$\Delta$ Net assets & 67,404 & 0.017 & 0.418 & -2.167 & -0.061 & 0.014 & 0.104 & 1.810 \\
\hline$\Delta R E D$ & 67,404 & -0.001 & 0.021 & -0.111 & 0.000 & 0.000 & 0.001 & 0.074 \\
\hline $\bar{\Delta}$ Interest expenses & 67,404 & 0.001 & 0.022 & -0.134 & -0.002 & 0.000 & 0.002 & 0.115 \\
\hline$\Delta$ Dividends & 67,404 & 0.000 & 0.009 & -0.051 & 0.000 & 0.000 & 0.000 & 0.038 \\
\hline Leverage & 67,404 & 0.203 & 0.223 & 0.000 & 0.009 & 0.131 & 0.321 & 0.883 \\
\hline Net financing & 67,404 & 0.036 & 0.214 & -0.715 & -0.031 & 0.001 & 0.053 & 1.160 \\
\hline$R 1 T R 2$ & 67,404 & 0.011 & 0.105 & 0.000 & 0.000 & 0.000 & 0.000 & 1.000 \\
\hline$R 2 T R 1$ & 67,404 & 0.013 & 0.114 & 0.000 & 0.000 & 0.000 & 0.000 & 1.000 \\
\hline$R 2 T N$ & 67,404 & 0.031 & 0.172 & 0.000 & 0.000 & 0.000 & 0.000 & 1.000 \\
\hline$N T R 2$ & 67,404 & 0.032 & 0.176 & 0.000 & 0.000 & 0.000 & 0.000 & 1.000 \\
\hline Cash/Total assets & 67,404 & 0.190 & 0.213 & 0.000 & 0.030 & 0.105 & 0.279 & 0.871 \\
\hline$R O A$ & 67,404 & -0.015 & 0.187 & -0.846 & -0.033 & 0.035 & 0.079 & 0.256 \\
\hline$R O E$ & 67,404 & -0.032 & 0.399 & -1.960 & -0.071 & 0.074 & 0.159 & 0.615 \\
\hline Nmargin & 67,404 & -0.237 & 1.299 & -9.320 & -0.028 & 0.030 & 0.078 & 0.351 \\
\hline AssetTO & 67,404 & 1.119 & 0.802 & 0.000 & 0.569 & 0.963 & 1.462 & 4.700 \\
\hline Age & 67,404 & 2.592 & 0.742 & 0.000 & 1.946 & 2.565 & 3.178 & 4.190 \\
\hline Size & 67,404 & 5.857 & 2.132 & 0.849 & 4.275 & 5.741 & 7.330 & 10.797 \\
\hline$M T B$ & 67,404 & 1.662 & 1.463 & 0.285 & 0.813 & 1.187 & 1.910 & 9.160 \\
\hline Tangibility & 67,404 & 0.273 & 0.236 & 0.000 & 0.086 & 0.196 & 0.400 & 0.997 \\
\hline Capital expenditure & 67,404 & 0.056 & 0.061 & 0.000 & 0.018 & 0.036 & 0.070 & 0.361 \\
\hline$G$-index & 17,341 & 8.998 & 2.678 & 2.000 & 7.000 & 9.000 & 11.000 & 17.000 \\
\hline E-index & 16,973 & 2.795 & 1.353 & 0.000 & 2.000 & 3.000 & 4.000 & 6.000 \\
\hline Block1 & 67,404 & 0.168 & 0.162 & 0.000 & 0.051 & 0.136 & 0.256 & 1.000 \\
\hline
\end{tabular}




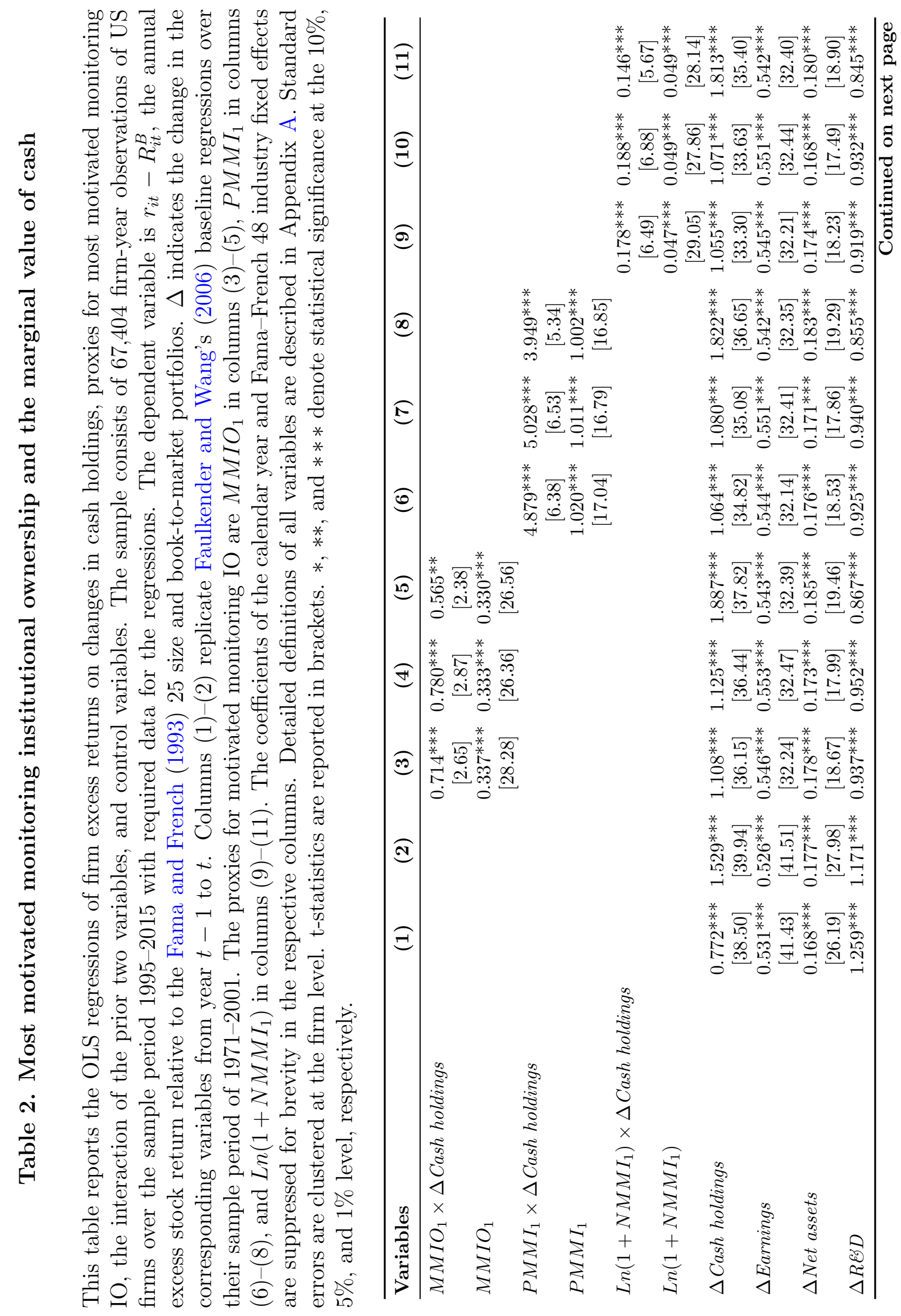




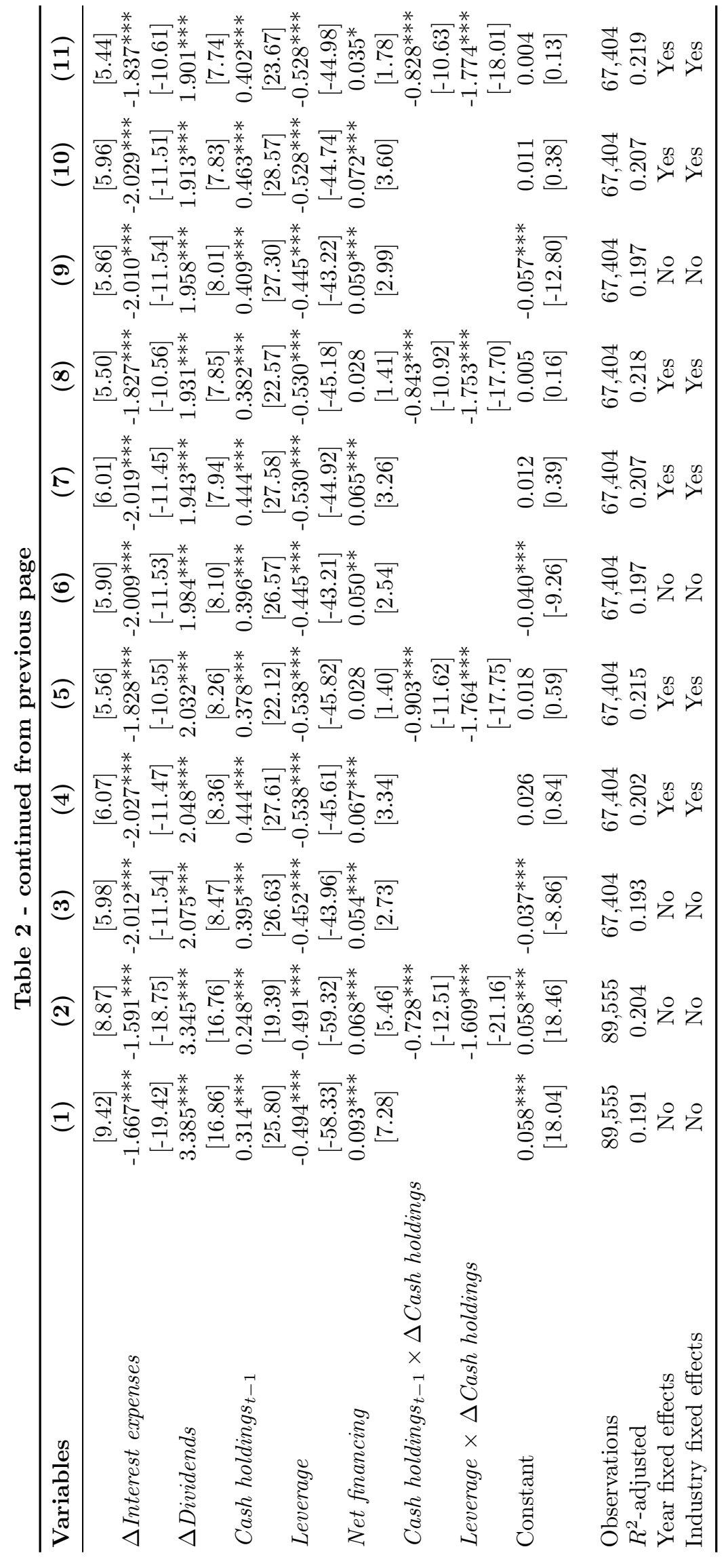




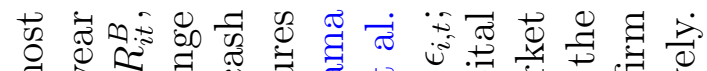

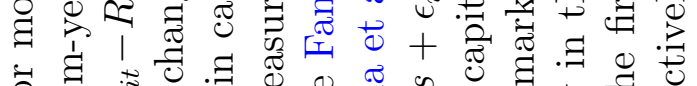

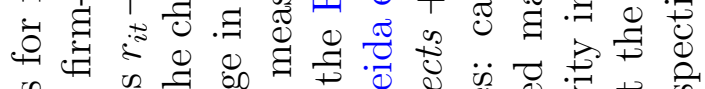

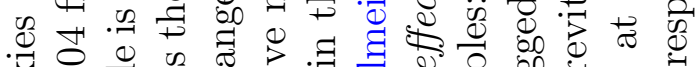

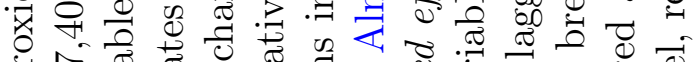
పิ का

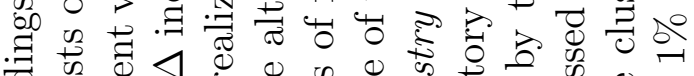

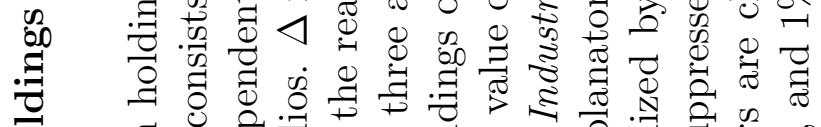
ङ ज्ञ

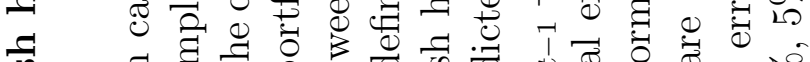

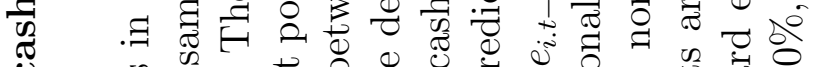

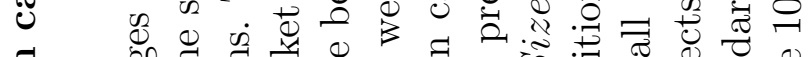

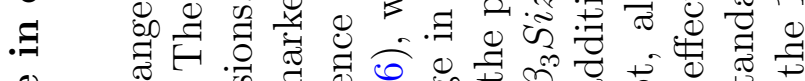

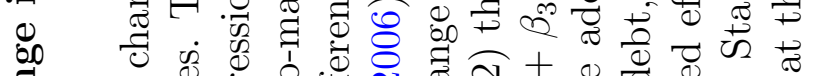

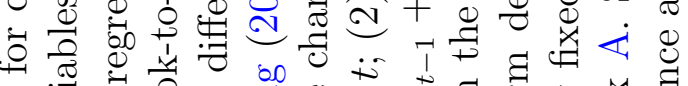
w

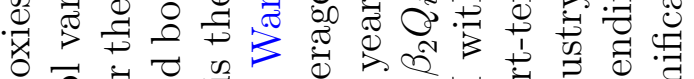

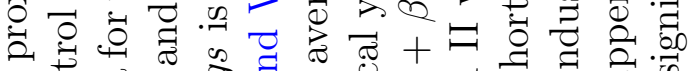
o $\begin{aligned} & \pi \\ & 0\end{aligned}$

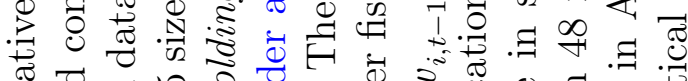

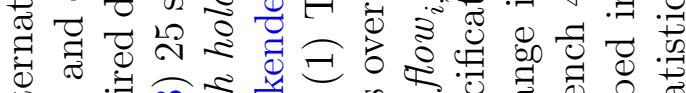
कै

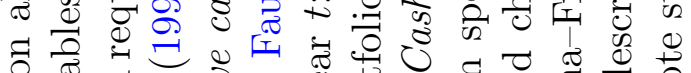
.

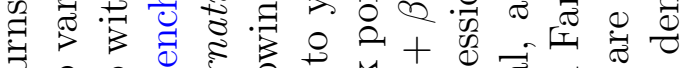

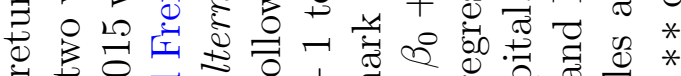

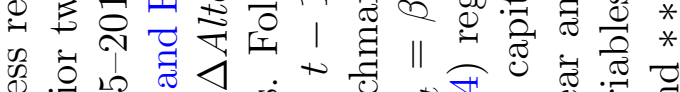

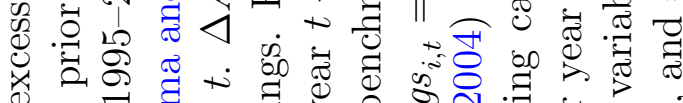

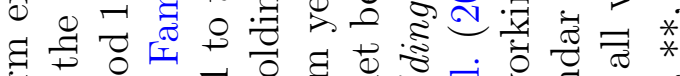

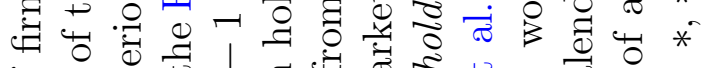

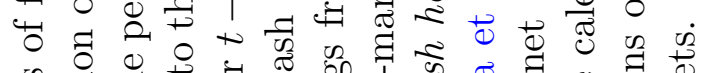

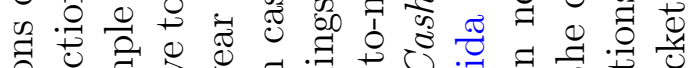

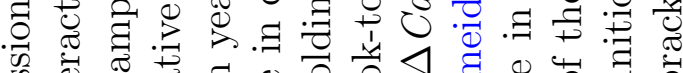

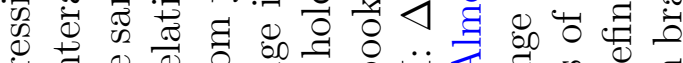

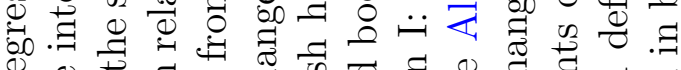

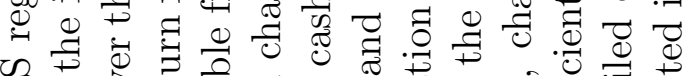

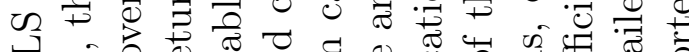
000

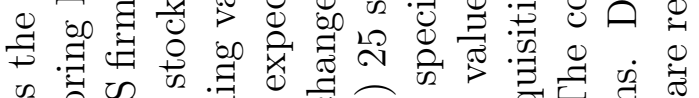

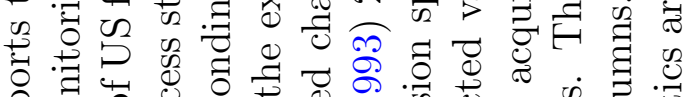

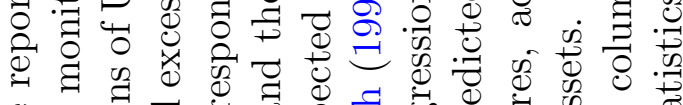

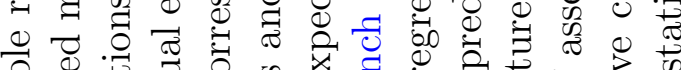

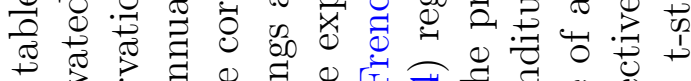

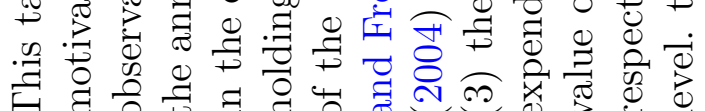

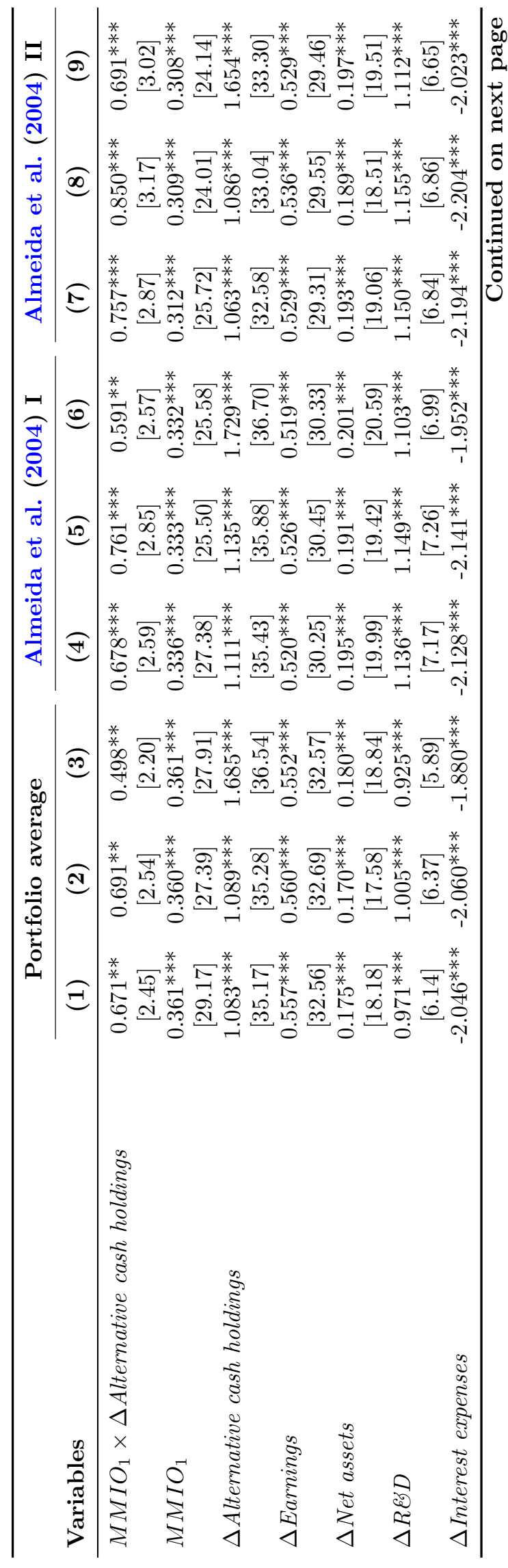




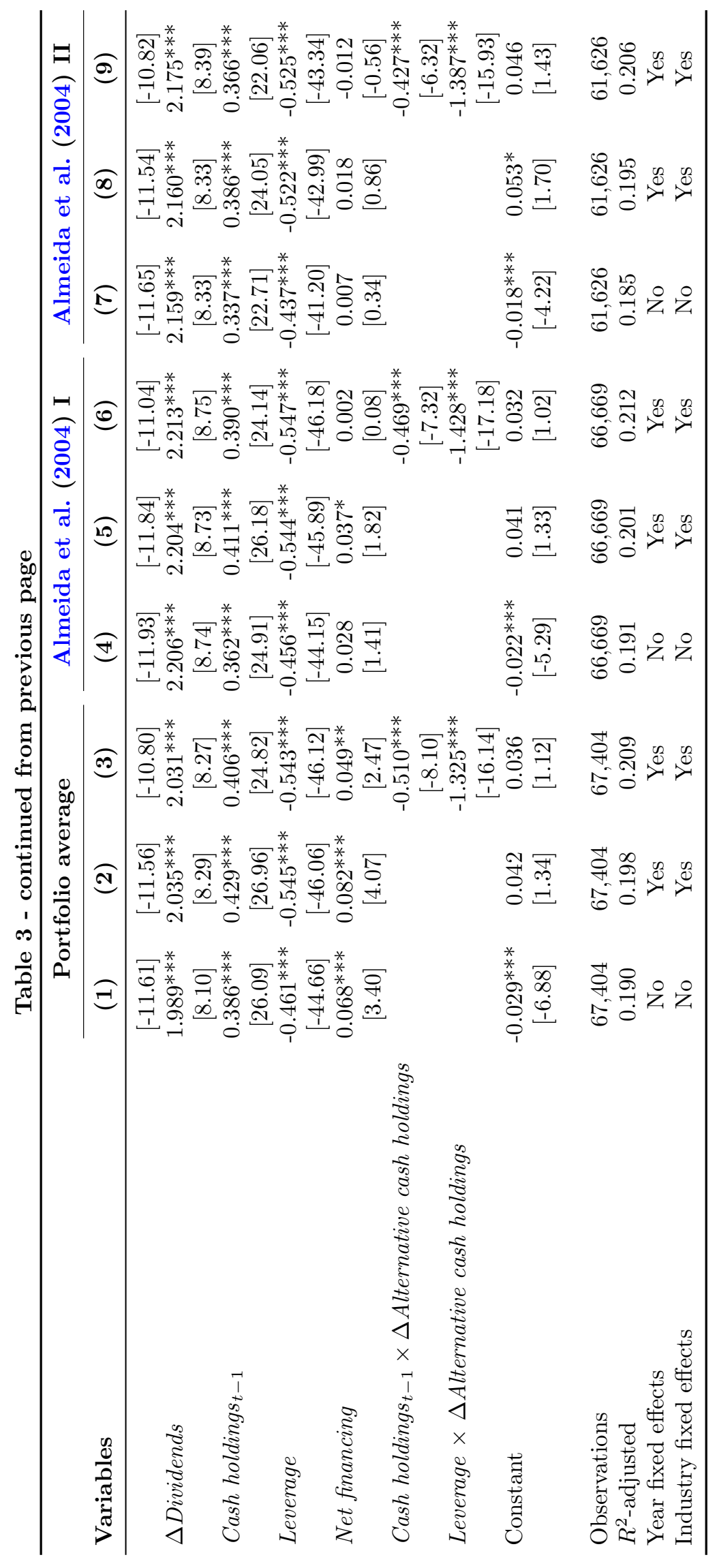




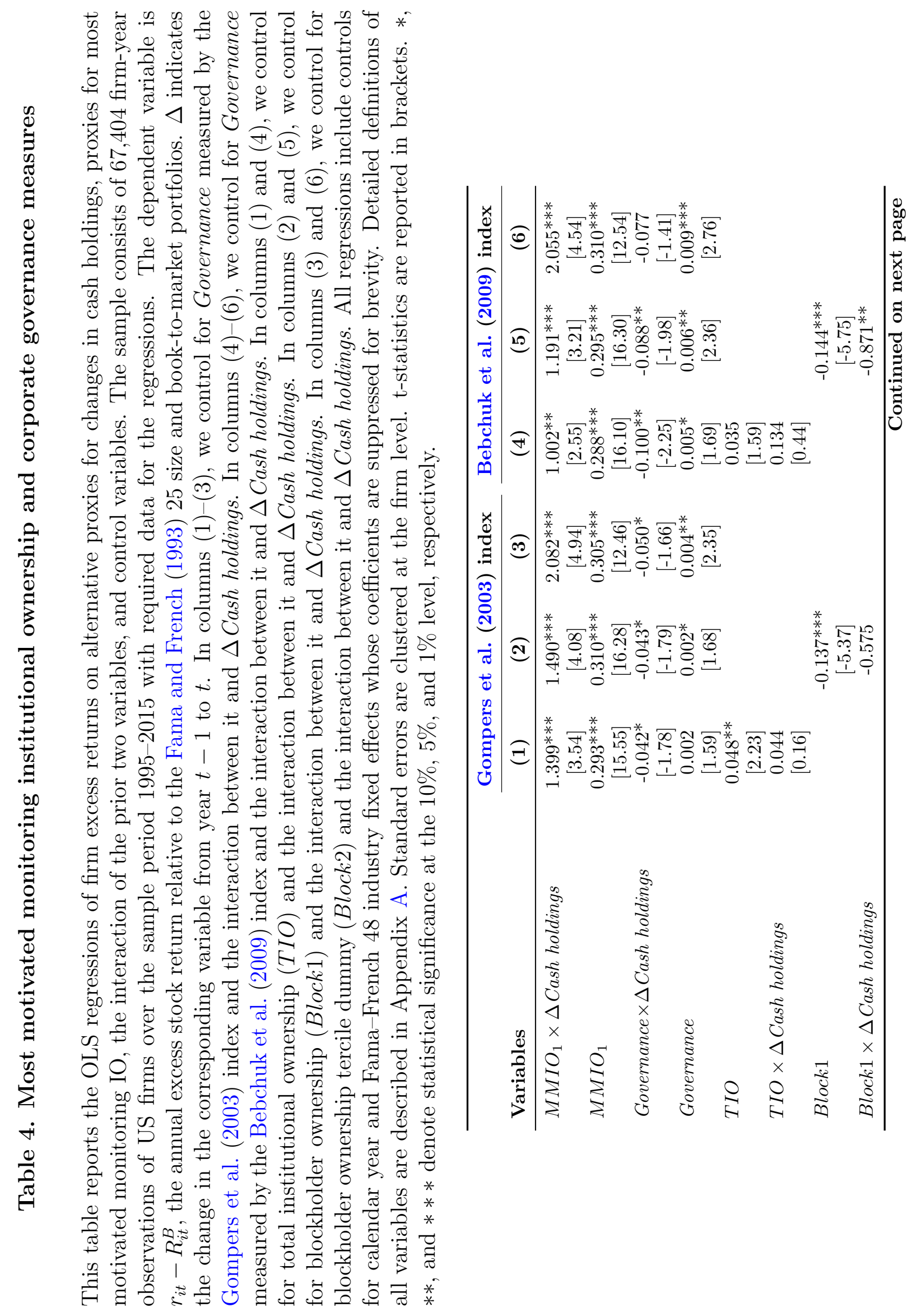




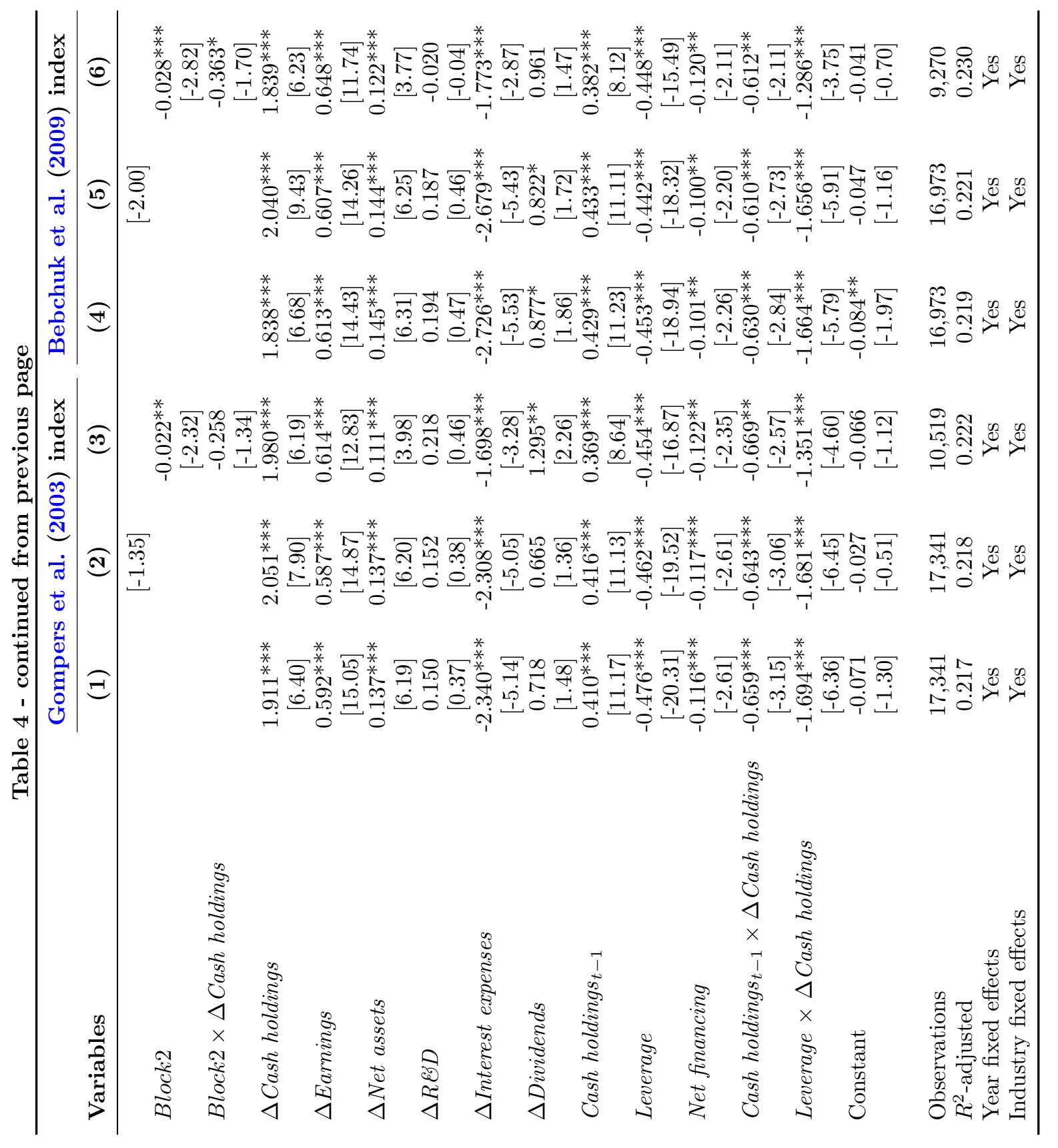




\section{Table 5. Most motivated monitoring institutional ownership by institutional investor type}

This table reports the OLS regressions of firm excess returns on changes in cash holdings, proxies for most motivated monitoring IO, the interaction of the prior two variables, and control variables. The sample consists of 67,404 firm-year observations of US firms over the sample period 1995-2015 with required data for the regressions. The dependent variable is $r_{i t}-R_{i t}^{B}$, the annual excess stock return relative to the Fama and French (1993) 25 size and book-to-market portfolios. $\Delta$ indicates the change in the corresponding variable from year $t-1$ to $t$. In columns (1) and (2), we divide $M M I O_{1}$ into most motivated monitoring independent IO $\left(M M I O_{1, \text { Independent }}\right)$ and most motivated monitoring grey IO $\left(M M I O_{1, \text { Grey }}\right)$. In columns (3)-(5), we follow Bushee (1998) and divide $M M I O_{1}$ into most motivated monitoring transient IO $\left(M M I O_{1, \text { Transient }}\right)$, most motivated monitoring quasi-indexer IO ( $\left.M M I O_{1, \text { Quasi-indexer }}\right)$, and most motivated monitoring dedicated IO ( $\left.M M I O_{1, \text { Dedicated }}\right)$. All regressions include controls for calendar year and Fama-French 48 industry fixed effects whose coefficients are suppressed for brevity. Detailed definitions of all variables are described in Appendix A. Standard errors are clustered at the firm level. t-statistics are reported in brackets. $*, * *$, and $* * *$ denote statistical significance at the $10 \%, 5 \%$, and $1 \%$ level, respectively.

\begin{tabular}{|c|c|c|c|c|c|}
\hline Variables & (1) & (2) & (3) & (4) & (5) \\
\hline$M M I O_{1, \text { Independent }} \times \Delta$ Cash holdings & $\begin{array}{c}0.769^{* *} \\
{[2.03]}\end{array}$ & & & & \\
\hline$M M I O_{1, \text { Grey }} \times \Delta$ Cash holdings & & $\begin{array}{c}1.424^{* * *} \\
{[2.72]}\end{array}$ & & & \\
\hline$M M I O_{1, \text { Transient }} \times \Delta$ Cash holdings & & & $\begin{array}{l}1.903^{*} \\
{[1.93]}\end{array}$ & & \\
\hline$M M I O_{1, \text { Quasi-indexer }} \times \Delta$ Cash holdings & & & & $\begin{array}{l}0.620^{*} \\
{[1.95]}\end{array}$ & \\
\hline$M M I O_{1, \text { Dedicated }} \times \Delta$ Cash holdings & & & & & $\begin{array}{l}0.118 \\
{[0.17]}\end{array}$ \\
\hline$M M I O_{1, \text { Independent }}$ & $\begin{array}{c}0.507^{* * *} \\
{[27.56]}\end{array}$ & & & & \\
\hline$M M I O_{1, \text { Grey }}$ & & $\begin{array}{c}0.364^{* * *} \\
{[11.63]}\end{array}$ & & & \\
\hline$M M I O_{1, \text { Transient }}$ & & & $\begin{array}{c}1.034^{* * *} \\
{[20.73]}\end{array}$ & & \\
\hline$M M I O_{1, Q u a s i-i n d e x e r}$ & & & & $\begin{array}{c}0.319^{* * *} \\
{[20.34]}\end{array}$ & \\
\hline$M M I O_{1, \text { Dedicated }}$ & & & & & $\begin{array}{c}0.521^{* * *} \\
{[10.00]}\end{array}$ \\
\hline$\Delta$ Cash holdings & $\begin{array}{c}1.128^{* * *} \\
{[36.44]}\end{array}$ & $\begin{array}{c}1.160^{* * *} \\
{[39.67]}\end{array}$ & $\begin{array}{c}1.122^{* * *} \\
{[34.63]}\end{array}$ & $\begin{array}{c}1.159^{* * *} \\
{[38.67]}\end{array}$ & $\begin{array}{c}1.169^{* * *} \\
{[41.13]}\end{array}$ \\
\hline$\Delta$ Earnings & $\begin{array}{c}0.553^{* * *} \\
{[32.48]}\end{array}$ & $\begin{array}{c}0.552^{* * *} \\
{[32.34]}\end{array}$ & $\begin{array}{c}0.551^{* * *} \\
{[32.35]}\end{array}$ & $\begin{array}{c}0.552^{* * *} \\
{[32.41]}\end{array}$ & $\begin{array}{c}0.552^{* * *} \\
{[32.30]}\end{array}$ \\
\hline$\Delta$ Net assets & $\begin{array}{c}0.172^{* * *} \\
{[17.88]}\end{array}$ & $\begin{array}{c}0.183^{* * *} \\
{[18.99]}\end{array}$ & $\begin{array}{c}0.173^{* * *} \\
{[17.99]}\end{array}$ & $\begin{array}{c}0.180^{* * *} \\
{[18.77]}\end{array}$ & $\begin{array}{c}0.184^{* * *} \\
{[19.16]}\end{array}$ \\
\hline$\Delta R \mathscr{E D}$ & $\begin{array}{c}0.940^{* * *} \\
{[6.00]}\end{array}$ & $\begin{array}{c}0.985^{* * *} \\
{[6.27]}\end{array}$ & $\begin{array}{c}0.914^{* * *} \\
{[5.83]}\end{array}$ & $\begin{array}{c}0.986^{* * *} \\
{[6.28]}\end{array}$ & $\begin{array}{l}0.974^{* * *} \\
{[6.19]}\end{array}$ \\
\hline
\end{tabular}


Table 5 - continued from previous page

\begin{tabular}{lccccc}
\hline Variables & $\mathbf{( 1 )}$ & $\mathbf{( 2 )}$ & $\mathbf{( 3 )}$ & $\mathbf{( 4 )}$ & $\mathbf{( 5 )}$ \\
\hline$\Delta$ Interest expenses & $-2.023^{* * *}$ & $-2.035^{* * *}$ & $-2.008^{* * *}$ & $-2.039^{* * *}$ & $-2.025^{* * *}$ \\
& {$[-11.45]$} & {$[-11.52]$} & {$[-11.34]$} & {$[-11.55]$} & {$[-11.48]$} \\
$\Delta$ Dividends & $2.020^{* * *}$ & $2.184^{* * *}$ & $2.091^{* * *}$ & $2.106^{* * *}$ & $2.227^{* * *}$ \\
& {$[8.28]$} & {$[8.86]$} & {$[8.54]$} & {$[8.56]$} & {$[9.05]$} \\
Cash holdings $t-1$ & $0.446^{* * *}$ & $0.423^{* * *}$ & $0.431^{* * *}$ & $0.435^{* * *}$ & $0.413^{* * *}$ \\
& {$[27.70]$} & {$[26.62]$} & {$[27.34]$} & {$[27.22]$} & {$[26.22]$} \\
Leverage & $-0.536^{* * *}$ & $-0.550^{* * *}$ & $-0.539^{* * *}$ & $-0.545^{* * *}$ & $-0.552^{* * *}$ \\
& {$[-45.43]$} & {$[-46.78]$} & {$[-46.16]$} & {$[-46.35]$} & {$[-46.98]$} \\
Net financing & $0.069^{* * *}$ & $0.051^{* *}$ & $0.055^{* * *}$ & $0.060^{* * *}$ & $0.047^{* *}$ \\
& {$[3.42]$} & {$[2.55]$} & {$[2.74]$} & {$[2.98]$} & {$[2.34]$} \\
Constant & 0.026 & 0.046 & 0.037 & 0.045 & 0.037 \\
& {$[0.85]$} & {$[1.48]$} & {$[1.18]$} & {$[1.49]$} & {$[1.20]$} \\
& & & & & \\
Observations & 67,404 & 67,404 & 67,404 & 67,404 & 67,404 \\
$R^{2}$-adjusted & 0.204 & 0.196 & 0.204 & 0.198 & 0.196 \\
Year fixed effects & Yes & Yes & Yes & Yes & Yes \\
Industry fixed effects & Yes & Yes & Yes & Yes & Yes \\
\hline
\end{tabular}




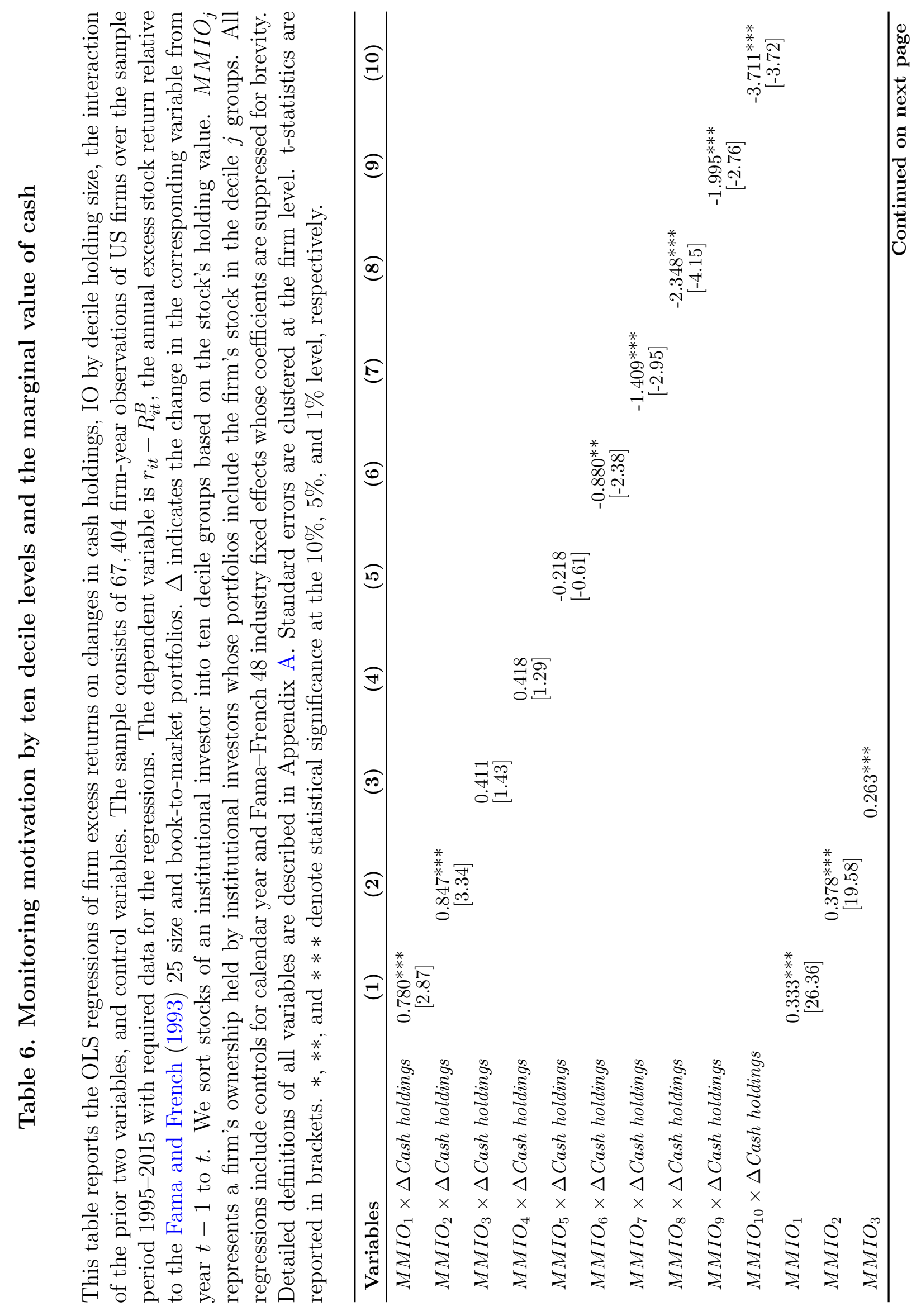




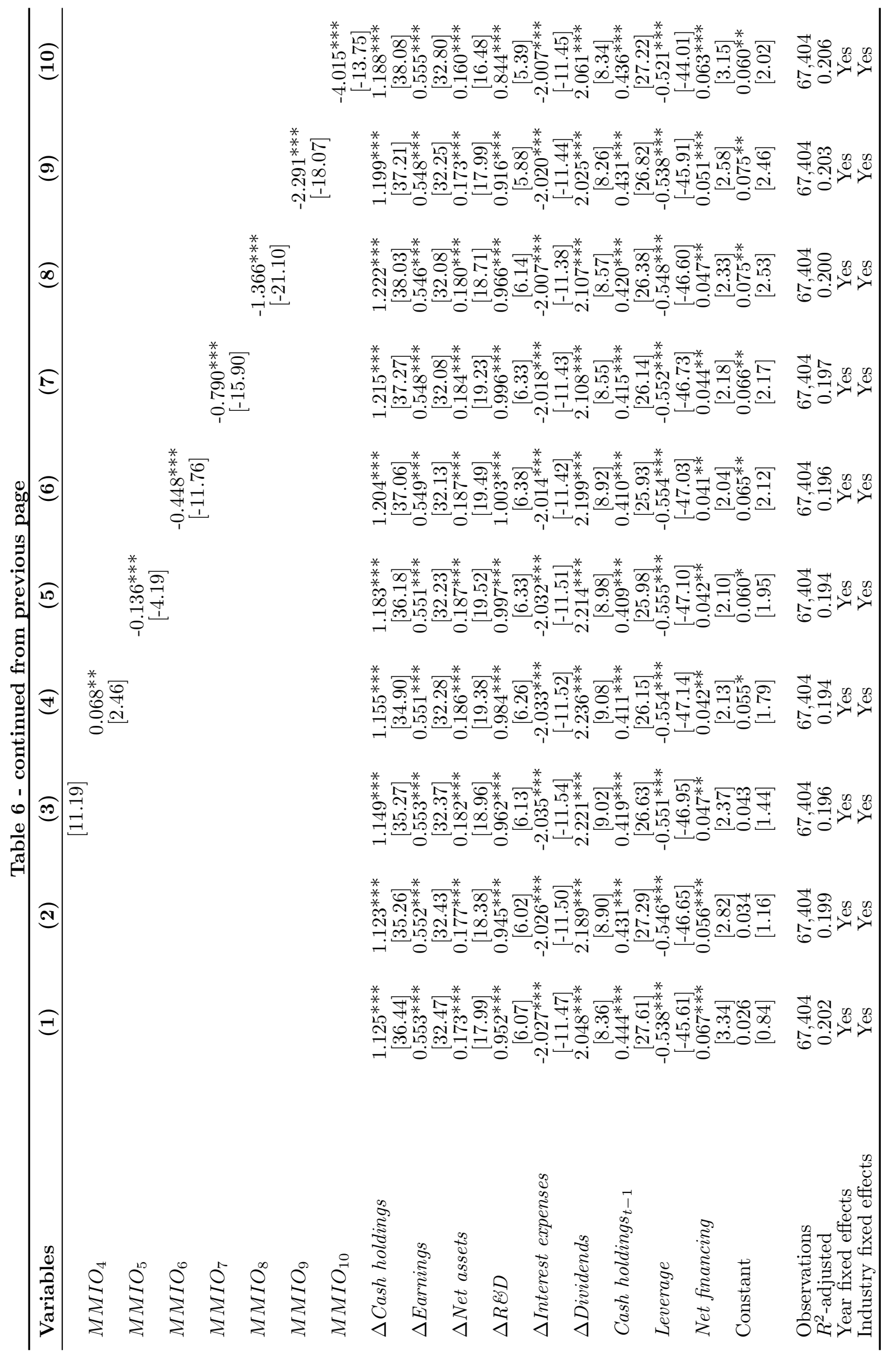




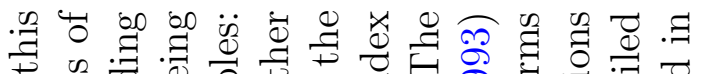
$\Xi$.

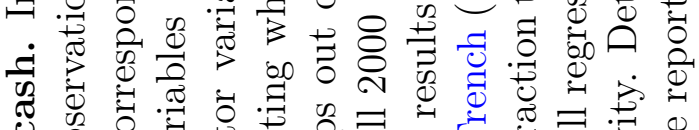

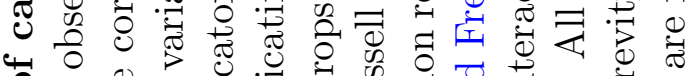
๑

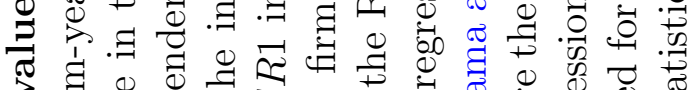

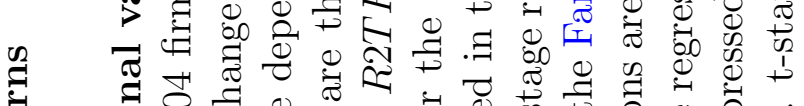

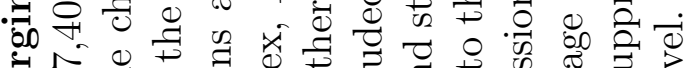
పี

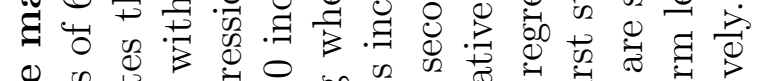
为类 0

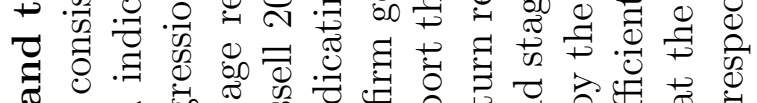

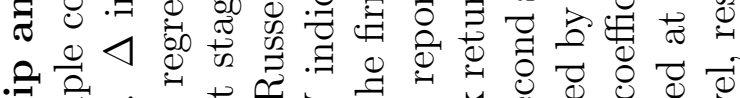
责 की I 0 की

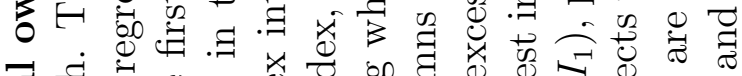
สี

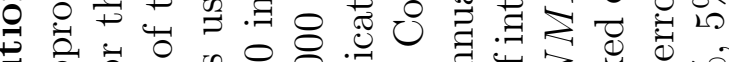

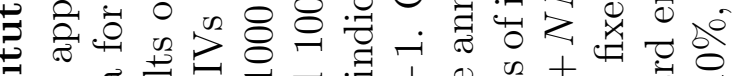
in

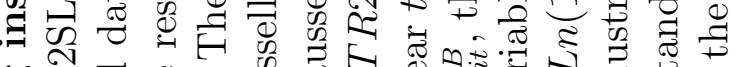

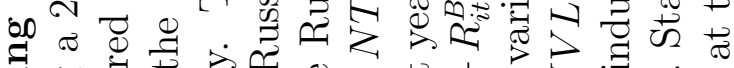

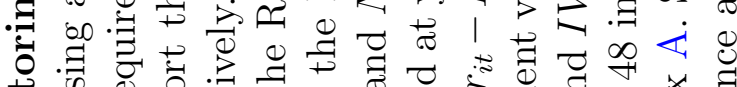

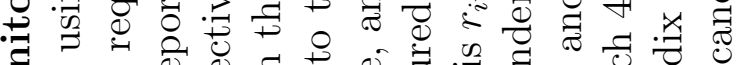

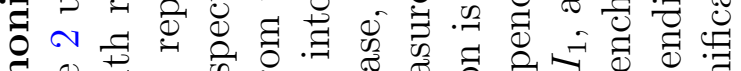

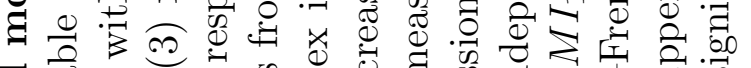
ठ

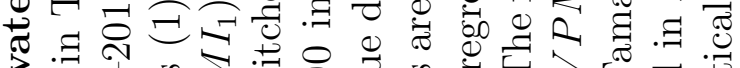
구의

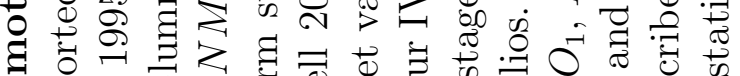

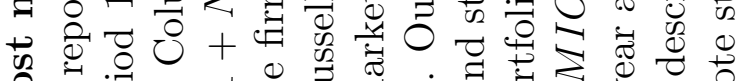

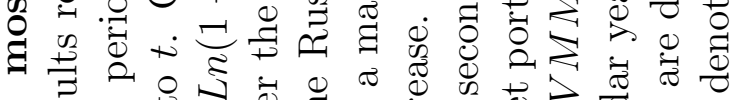

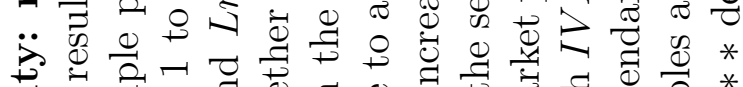
氜范

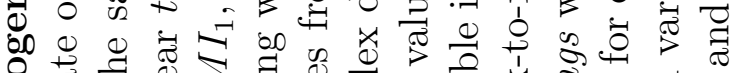

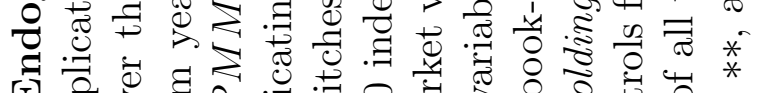

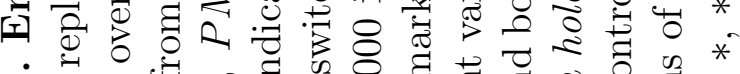

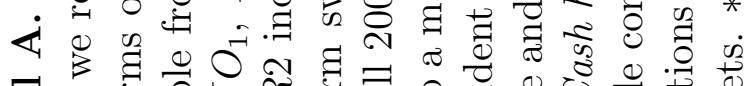

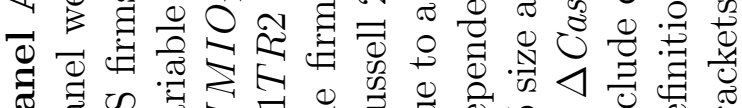

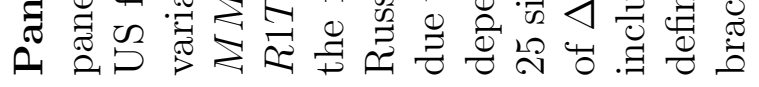

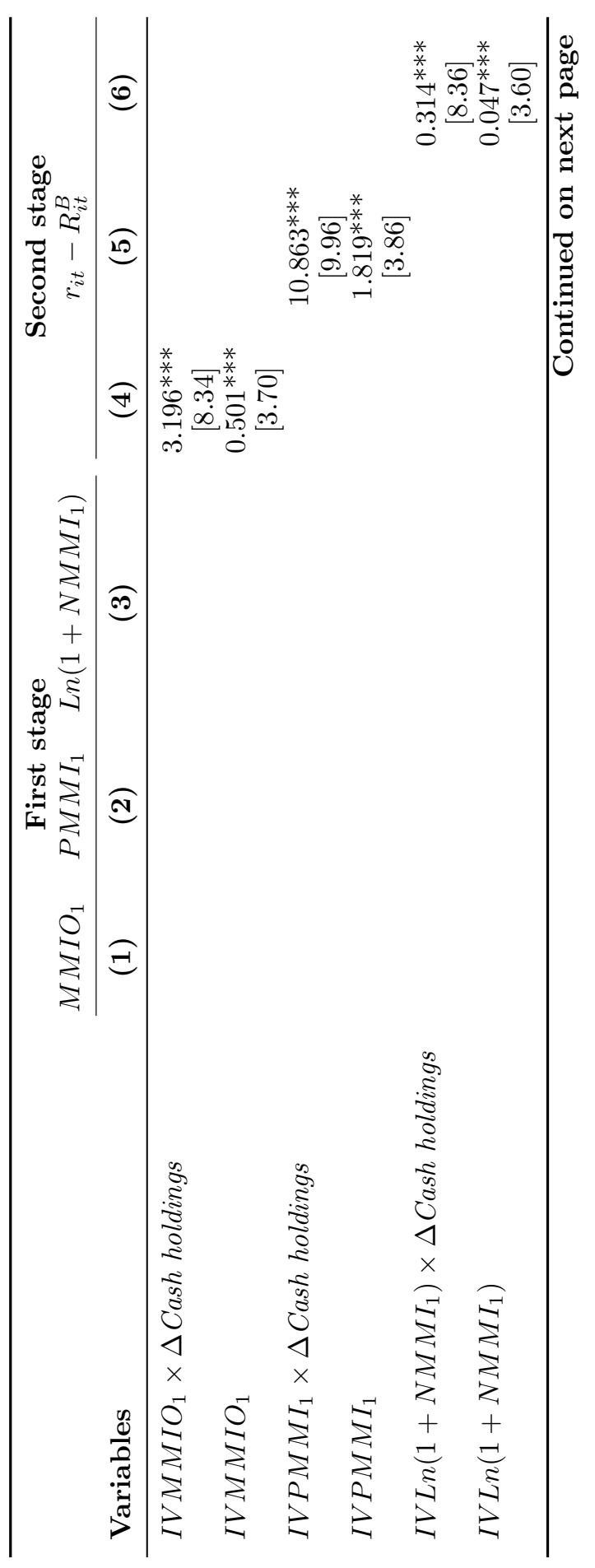




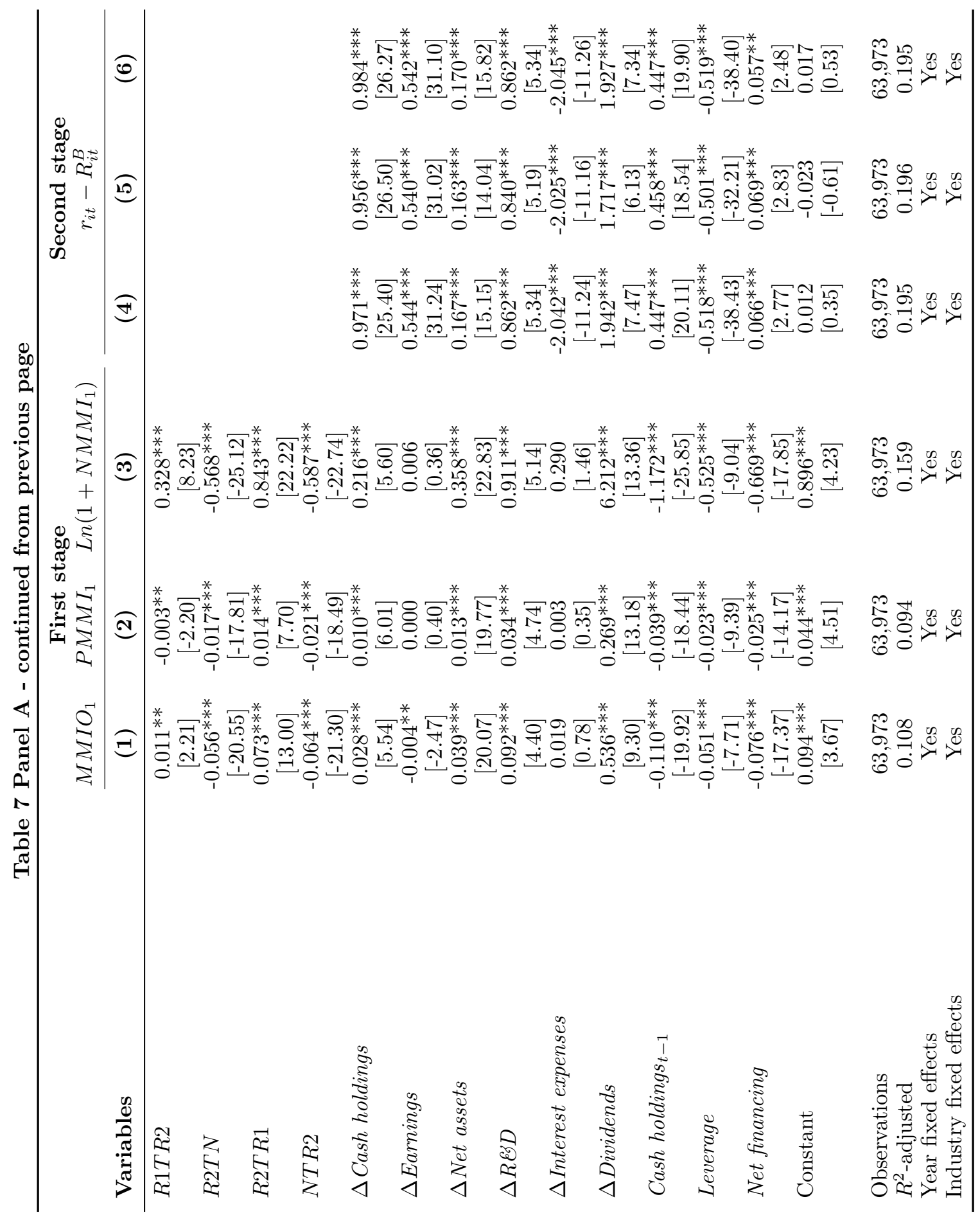




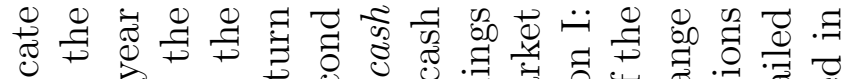

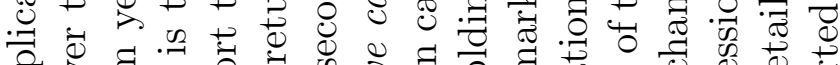
过

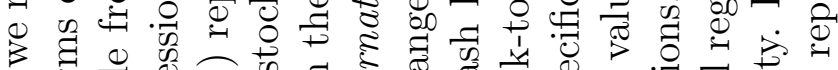

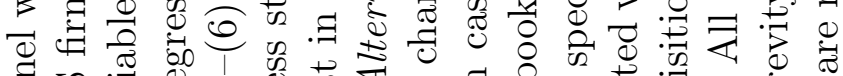

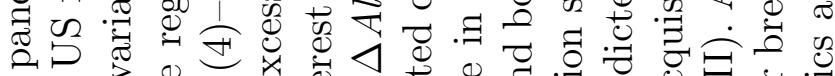

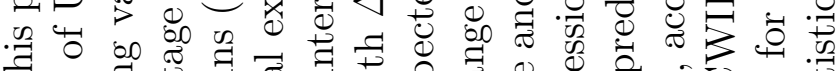
ॠ $\exists . \overline{0}$ क

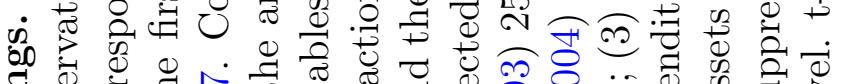
$\Xi$ 㟧

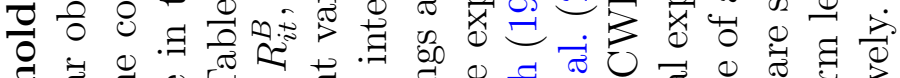

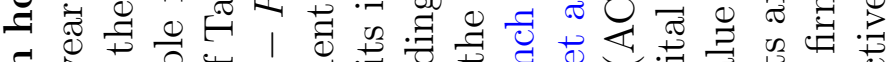
जी $\Rightarrow$.

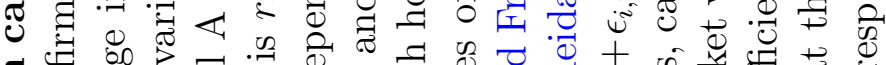
$\exists 4$

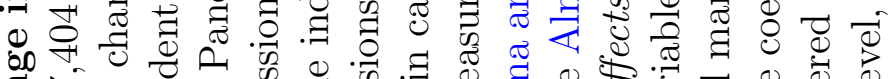
他

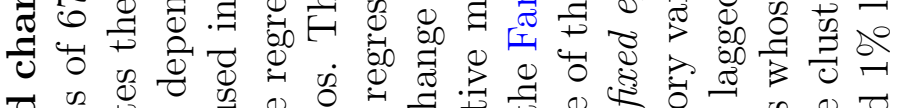

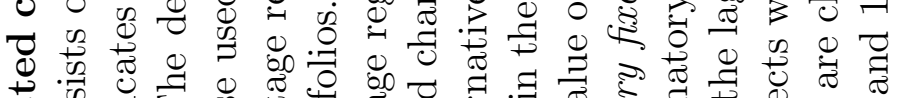

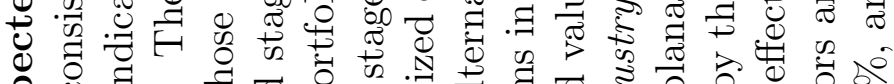
잉 ब.

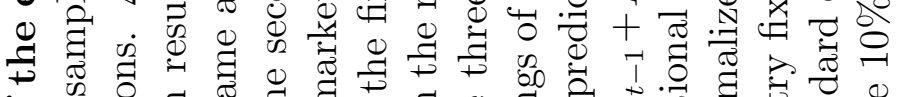

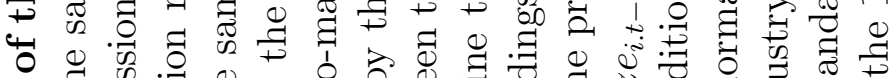
U

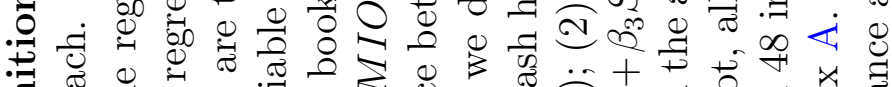
च

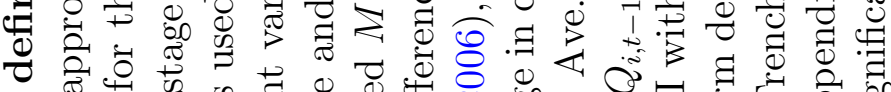

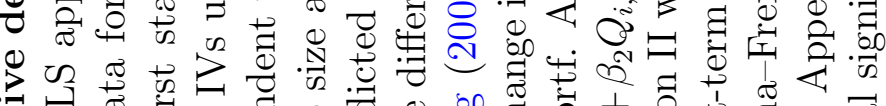

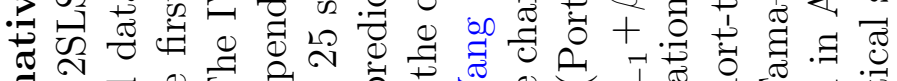
व $\approx$ व

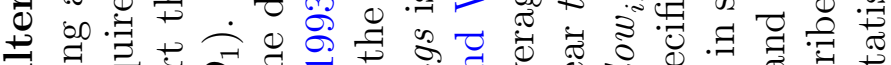

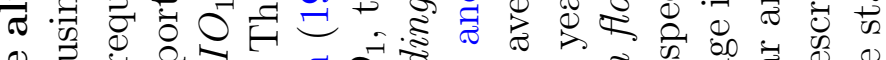

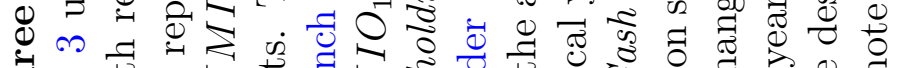
表落

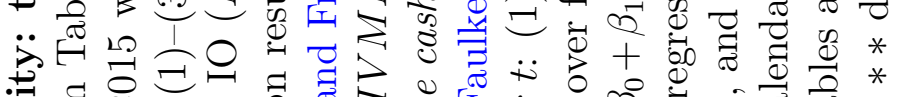

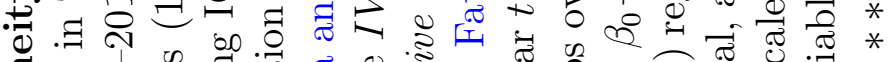

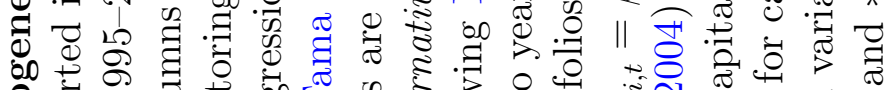

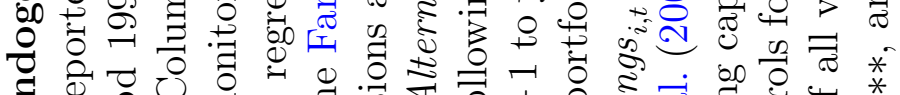
用

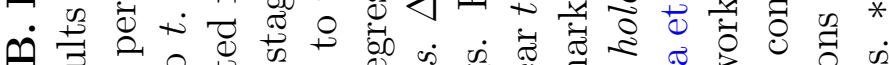

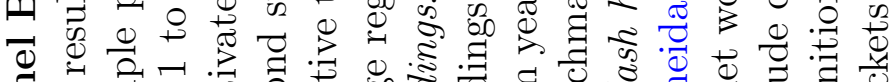

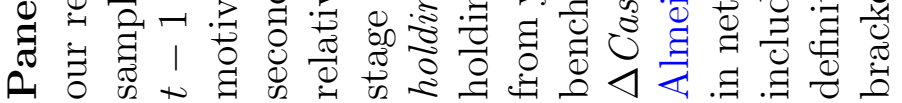

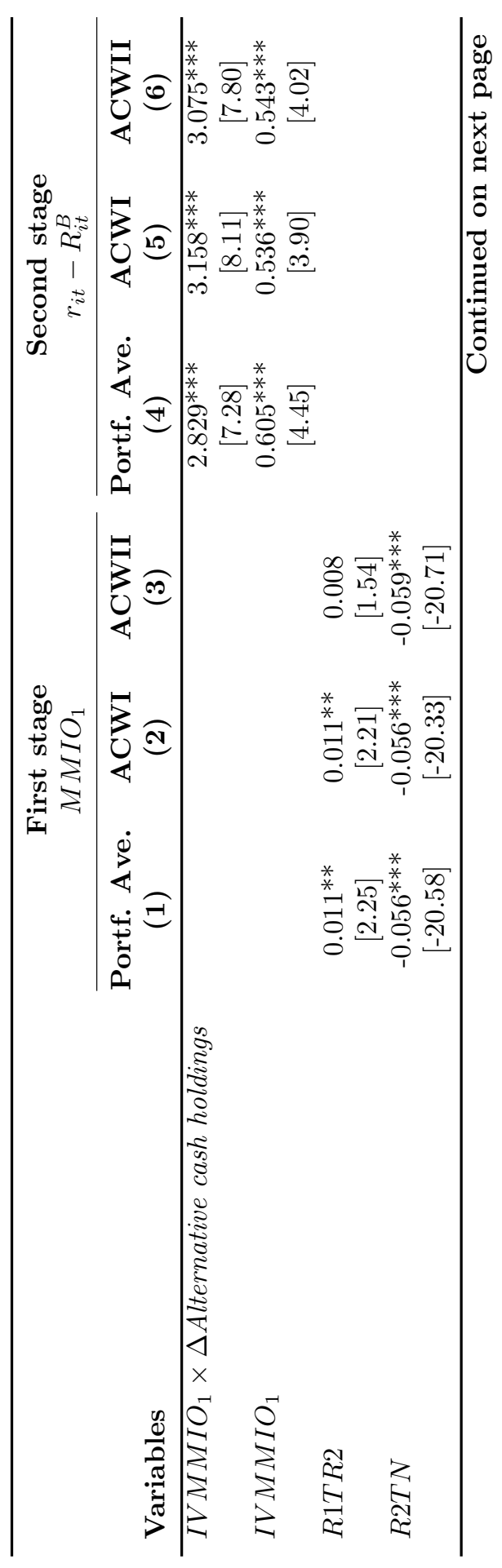




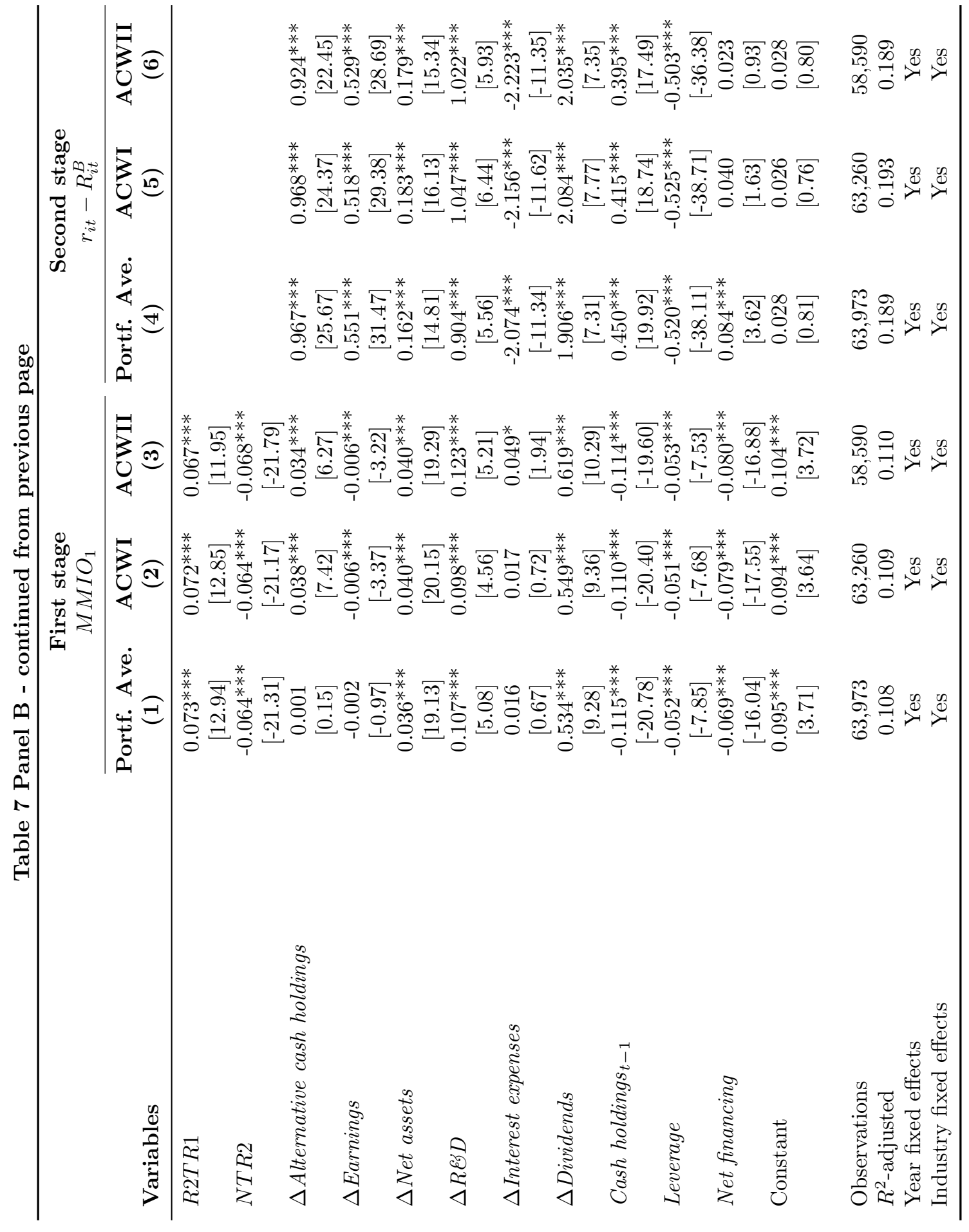


Table 8. Using high-dimensional fixed effects to mitigate endogeneity concerns

This table reports the OLS regressions of firm excess returns on changes in cash holdings, most motivated monitoring IO, the interaction of the prior two variables, and control variables. The sample consists of 67,404 firm-year observations of US firms over the sample period 1995-2015 with required data for the regressions. The dependent variable is $r_{i t}-R_{i t}^{B}$, the annual excess stock return relative to the Fama and French (1993) 25 size and book-tomarket portfolios. $\Delta$ indicates the change in the corresponding variable from year $t-1$ to t. Following Gormley and Matsa (2014), we use the high-dimensional fixed effects model to control for unobserved firm characteristics. In columns (1) and (2), we control for the firm and year fixed effects. In columns (3) and (4), we control for the firm $\times$ year $\times$ Fama-French 48 industry fixed effects. The coefficients of fixed effects are suppressed for brevity. Detailed definitions of all variables are described in Appendix A. Standard errors are clustered at the firm level. t-statistics are reported in brackets. $*, * *$, and $* * *$ denote statistical significance at the $10 \%, 5 \%$, and $1 \%$ level, respectively.

\begin{tabular}{|c|c|c|c|c|}
\hline Variables & (1) & $(2)$ & (3) & $(4)$ \\
\hline$M M I O_{1} \times \Delta$ Cash holdings & $\begin{array}{c}0.434^{* * *} \\
{[15.94]}\end{array}$ & $\begin{array}{c}0.419^{* * *} \\
{[15.64]}\end{array}$ & $\begin{array}{c}0.383^{* * *} \\
{[14.46]}\end{array}$ & $\begin{array}{c}0.370^{* * *} \\
{[14.13]}\end{array}$ \\
\hline$M M I O_{1}$ & $\begin{array}{c}0.838^{* * *} \\
{[3.53]}\end{array}$ & $\begin{array}{c}0.748^{* * *} \\
{[3.57]}\end{array}$ & $\begin{array}{c}0.625^{* * *} \\
{[2.91]}\end{array}$ & $\begin{array}{c}0.565^{* * *} \\
{[2.90]}\end{array}$ \\
\hline$\Delta$ Cash holdings & $\begin{array}{c}1.264^{* * *} \\
{[38.53]}\end{array}$ & $\begin{array}{c}1.925^{* * *} \\
{[37.46]}\end{array}$ & $\begin{array}{c}1.219^{* * *} \\
{[37.78]}\end{array}$ & $\begin{array}{c}1.831^{* * *} \\
{[36.55]}\end{array}$ \\
\hline$\Delta$ Earnings & $\begin{array}{c}0.473^{* * *} \\
{[28.48]}\end{array}$ & $\begin{array}{c}0.466^{* * *} \\
{[28.41]}\end{array}$ & $\begin{array}{c}0.459^{* * *} \\
{[27.82]}\end{array}$ & $\begin{array}{c}0.453^{* * *} \\
{[27.74]}\end{array}$ \\
\hline$\Delta$ Net assets & $\begin{array}{c}0.122^{* * *} \\
{[11.43]}\end{array}$ & $\begin{array}{c}0.132^{* * *} \\
{[12.47]}\end{array}$ & $\begin{array}{c}0.123^{* * *} \\
{[11.68]}\end{array}$ & $\begin{array}{c}0.131^{* * *} \\
{[12.64]}\end{array}$ \\
\hline$\Delta R \& D$ & $\begin{array}{c}0.723^{* * *} \\
{[4.37]}\end{array}$ & $\begin{array}{c}0.661^{* * *} \\
{[4.02]}\end{array}$ & $\begin{array}{c}0.682^{* * *} \\
{[4.15]}\end{array}$ & $\begin{array}{c}0.621^{* * *} \\
{[3.81]}\end{array}$ \\
\hline$\Delta$ Interest expenses & $\begin{array}{c}-1.216^{* * *} \\
{[-6.66]}\end{array}$ & $\begin{array}{c}-1.049^{* * *} \\
{[-5.84]}\end{array}$ & $\begin{array}{c}-1.094^{* * *} \\
{[-6.11]}\end{array}$ & $\begin{array}{c}-0.937^{* * * *} \\
{[-5.32]}\end{array}$ \\
\hline$\Delta$ Dividends & $\begin{array}{c}1.064^{* * *} \\
{[4.21]}\end{array}$ & $\begin{array}{c}1.079^{* * *} \\
{[4.25]}\end{array}$ & $\begin{array}{c}1.273^{* * *} \\
{[5.20]}\end{array}$ & $\begin{array}{c}1.292^{* * * *} \\
{[5.24]}\end{array}$ \\
\hline Cash holdings $_{t-1}$ & $\begin{array}{c}1.032^{* * *} \\
{[40.95]}\end{array}$ & $\begin{array}{c}0.974^{* * *} \\
{[37.79]}\end{array}$ & $\begin{array}{c}1.012^{* * *} \\
{[40.78]}\end{array}$ & $\begin{array}{c}0.961^{* * *} \\
{[37.75]}\end{array}$ \\
\hline Leverage & $\begin{array}{c}-1.154^{* * *} \\
{[-49.76]}\end{array}$ & $\begin{array}{c}-1.154^{* * *} \\
{[-49.80]}\end{array}$ & $\begin{array}{c}-1.115^{* * *} \\
{[-49.26]}\end{array}$ & $\begin{array}{c}-1.118^{* * *} \\
{[-49.51]}\end{array}$ \\
\hline Net financing & $\begin{array}{c}0.136^{* * *} \\
{[6.13]}\end{array}$ & $\begin{array}{c}0.101^{* * *} \\
{[4.64]}\end{array}$ & $\begin{array}{c}0.128^{* * *} \\
{[5.89]}\end{array}$ & $\begin{array}{c}0.097^{* * *} \\
{[4.53]}\end{array}$ \\
\hline Cash holdings $_{t-1} \times \Delta$ Cash holdings & & $\begin{array}{c}-0.645^{* * *} \\
{[-8.06]}\end{array}$ & & $\begin{array}{c}-0.569^{* * *} \\
{[-7.21]}\end{array}$ \\
\hline Leverage $\times \Delta$ Cash holdings & & $\begin{array}{c}-1.865^{* * *} \\
{[-18.34]}\end{array}$ & & $\begin{array}{c}-1.785^{* * *} \\
{[-17.76]}\end{array}$ \\
\hline Observations & 67,404 & 67,404 & 67,404 & 67,404 \\
\hline$R^{2}$-adjusted & 0.251 & 0.262 & 0.297 & 0.306 \\
\hline Year fixed effects & Yes & Yes & No & No \\
\hline Firm fixed effects & Yes & Yes & No & No \\
\hline Firm $\times$ Year $\times$ Industry fixed effects & No & No & Yes & Yes \\
\hline
\end{tabular}



Table 9. Using changes in most motivated monitoring institutional ownership
to mitigate endogeneity concerns

This table reports the OLS regressions of firm excess returns on changes in cash holdings, changes in most motivated monitoring IO, the interaction of the prior two variables, and control variables. The sample consists of 67,404 firm-year observations of US firms over the sample period 1995-2015 with required data for the regressions. The dependent variable is $r_{i t}-R_{i t}^{B}$, the annual excess stock return relative to the Fama and French (1993) 25 size and book-to-market portfolios. $\triangle^{\prime} M M I O_{1}$ represents the change in $M M I O_{1}$ from March to September year $t$. $\Delta$ indicates the change in the corresponding variable from year $t-1$ to $t$. The coefficients of the calendar year and Fama-French 48 industry fixed effects are suppressed for brevity in columns (2) and (3). Detailed definitions of all variables are described in Appendix A. Standard errors are clustered at the firm level. t-statistics are reported in brackets. $*, * *$, and $* * *$ denote statistical significance at the $10 \%, 5 \%$, and $1 \%$ level, respectively.

\begin{tabular}{|c|c|c|c|}
\hline Variables & (1) & $(2)$ & (3) \\
\hline$\Delta^{\prime} M M I O_{1} \times \Delta$ Cash holdings & $\begin{array}{c}1.617^{* * *} \\
{[2.91]}\end{array}$ & $\begin{array}{c}1.629^{* * *} \\
{[3.00]}\end{array}$ & $\begin{array}{c}1.438^{* * *} \\
{[2.70]}\end{array}$ \\
\hline$\Delta^{\prime} M M I O_{1}$ & $\begin{array}{c}1.022^{* * * *} \\
{[30.72]}\end{array}$ & $\begin{array}{c}1.013^{* * *} * \\
{[30.59]}\end{array}$ & $\begin{array}{c}1.002^{* * *} * \\
{[30.26]}\end{array}$ \\
\hline$\Delta$ Cash holdings & $\begin{array}{c}1.120^{* * *} \\
{[39.92]}\end{array}$ & $\begin{array}{c}1.139^{* * *} \\
{[40.20]}\end{array}$ & $\begin{array}{c}1.893^{* * *} \\
{[40.55]}\end{array}$ \\
\hline$\Delta$ Earnings & $\begin{array}{c}0.534^{* * *} \\
{[31.63]}\end{array}$ & $\begin{array}{c}0.543^{* * *} \\
{[31.95]}\end{array}$ & $\begin{array}{c}0.533^{* * *} \\
{[31.89]}\end{array}$ \\
\hline$\Delta$ Net assets & $\begin{array}{c}0.189^{* * * *} \\
{[20.03]}\end{array}$ & $\begin{array}{c}0.184^{* * *} \\
{[19.34]}\end{array}$ & $\begin{array}{c}0.196^{* * * *} \\
{[20.80]}\end{array}$ \\
\hline$\triangle R \mathscr{E} D$ & $\begin{array}{c}0.946^{* * *} \\
{[6.04]}\end{array}$ & $\begin{array}{c}0.956^{* * *} \\
{[6.10]}\end{array}$ & $\begin{array}{c}0.873^{* * *} \\
{[5.60]}\end{array}$ \\
\hline$\Delta$ Interest expenses & $\begin{array}{c}-2.010 * * * \\
{[-11.60]}\end{array}$ & $\begin{array}{c}-2.012^{* * *} \\
{[-11.46]}\end{array}$ & $\begin{array}{c}-1.813^{* * *} \\
{[-10.53]}\end{array}$ \\
\hline$\Delta$ Dividends & $\begin{array}{c}2.325^{* * *} \\
{[9.53]}\end{array}$ & $\begin{array}{c}2.269 * * * \\
{[9.32]}\end{array}$ & $\begin{array}{c}2.251^{* * *} \\
{[9.21]}\end{array}$ \\
\hline Cash holdings $_{t-1}$ & $\begin{array}{c}0.353^{* * *} \\
{[24.37]}\end{array}$ & $\begin{array}{c}0.399^{* * *} \\
{[25.50]}\end{array}$ & $\begin{array}{c}0.332^{* * *} * \\
{[20.00]}\end{array}$ \\
\hline Leverage & $\begin{array}{c}-0.454^{* * *} \\
{[-44.81]}\end{array}$ & $\begin{array}{c}-0.542^{* * *} \\
{[-46.30]}\end{array}$ & $\begin{array}{c}-0.541 * * * \\
{[-46.40]}\end{array}$ \\
\hline Net financing & $\begin{array}{l}0.025 \\
{[1.29]}\end{array}$ & $\begin{array}{c}0.040^{* *} \\
{[2.04]}\end{array}$ & $\begin{array}{l}0.001 \\
{[0.06]}\end{array}$ \\
\hline Cash holdings $_{t-1} \times \Delta$ Cash holdings & & & $\begin{array}{c}-0.914 * * * \\
{[-12.02]}\end{array}$ \\
\hline Leverage $\times \Delta$ Cash holdings & & & $\begin{array}{c}-1.750 * * * \\
{[-17.62]}\end{array}$ \\
\hline Constant & $\begin{array}{c}0.009^{* *} \\
{[2.55]}\end{array}$ & $\begin{array}{l}0.043 \\
{[1.43]}\end{array}$ & $\begin{array}{l}0.036 \\
{[1.17]}\end{array}$ \\
\hline Observations & 67,404 & 67,404 & 67,404 \\
\hline$R^{2}$-adjusted & 0.200 & 0.210 & 0.222 \\
\hline Year fixed effects & No & Yes & Yes \\
\hline Industry fixed effects & No & Yes & Yes \\
\hline
\end{tabular}




\section{Table 10. Monitoring motivation-weighted institutional ownership and the marginal value of cash}

This table reports the regressions of firm excess returns on changes in cash holdings, monitoring motivation-weighted IO (TMA), the interaction of the prior two variables, and control variables. The sample consists of 67,404 firm-year observations of US firms over the sample period 1995-2015 with required data for the regressions. The dependent variable is $r_{i t}-R_{i t}^{B}$, the annual excess stock return relative to the Fama and French (1993) 25 size and book-to-market portfolios. $\Delta$ indicates the change in the corresponding variable from year $t-1$ to $t$. Columns (1)-(2) report the OLS regression results. Columns (3)-(4) report the second stage regression results of the 2SLS regressions similar to those reported in Panel A of Table 7. The coefficients of the calendar year and Fama-French 48 industry fixed effects are suppressed for brevity. Detailed definitions of all variables are described in Appendix A. Standard errors are clustered at the firm level. t-statistics are reported in brackets. $*, * *$, and $* * *$ denote statistical significance at the $10 \%, 5 \%$, and $1 \%$ level, respectively.

\begin{tabular}{|c|c|c|c|c|}
\hline \multirow[b]{2}{*}{ Variables } & \multicolumn{2}{|c|}{ OLS } & \multicolumn{2}{|c|}{ 2SLS } \\
\hline & (1) & $(2)$ & (3) & $(4)$ \\
\hline$T M A \times \Delta$ Cash holdings & $\begin{array}{c}0.037^{* *} \\
{[2.52]}\end{array}$ & $\begin{array}{c}0.039^{* * *} \\
{[2.69]}\end{array}$ & & \\
\hline$T M A$ & $\begin{array}{c}0.032^{* * *} \\
{[22.66]}\end{array}$ & $\begin{array}{c}0.034^{* * *} \\
{[22.18]}\end{array}$ & & \\
\hline IVTMA $\times \Delta$ Cash holdings & & & $\begin{array}{c}0.221^{* * *} \\
{[14.58]}\end{array}$ & $\begin{array}{c}0.023^{* * *} \\
{[6.53]}\end{array}$ \\
\hline$I V T M A$ & & & $\begin{array}{c}0.466^{* * *} \\
{[9.93]}\end{array}$ & $\begin{array}{c}0.238^{* * * *} \\
{[7.08]}\end{array}$ \\
\hline$\Delta$ Cash holdings & $\begin{array}{c}1.063^{* * *} \\
{[25.89]}\end{array}$ & $\begin{array}{c}1.078^{* * *} \\
{[26.19]}\end{array}$ & $\begin{array}{l}-0.021 \\
{[-0.18]}\end{array}$ & $\begin{array}{c}0.624^{* * *} * \\
{[7.61]}\end{array}$ \\
\hline$\Delta$ Earnings & $\begin{array}{c}0.550^{* * *} \\
{[32.40]}\end{array}$ & $\begin{array}{c}0.556^{* * *} \\
{[32.64]}\end{array}$ & $\begin{array}{c}0.568^{* * *} \\
{[33.30]}\end{array}$ & $\begin{array}{c}0.543^{* * * *} \\
{[31.99]}\end{array}$ \\
\hline$\Delta$ Net assets & $\begin{array}{c}0.178^{* * *} \\
{[18.50]}\end{array}$ & $\begin{array}{c}0.171^{* * *} \\
{[17.70]}\end{array}$ & $\begin{array}{c}0.093^{* * *} \\
{[7.91]}\end{array}$ & $\begin{array}{c}0.182^{* * * *} \\
{[18.67]}\end{array}$ \\
\hline$\Delta R \mathscr{E} D$ & $\begin{array}{c}0.883^{* * *} * \\
{[5.63]}\end{array}$ & $\begin{array}{c}0.900^{* * *} * \\
{[5.75]}\end{array}$ & $\begin{array}{c}0.419^{* *} \\
{[2.57]}\end{array}$ & $\begin{array}{c}0.924^{* * * *} \\
{[5.84]}\end{array}$ \\
\hline$\Delta$ Interest expenses & $\begin{array}{c}-2.019^{* * *} \\
{[-11.54]}\end{array}$ & $\begin{array}{c}-2.037^{* * *} \\
{[-11.50]}\end{array}$ & $\begin{array}{l}-1.915^{* * *} \\
{[-11.09]}\end{array}$ & $\begin{array}{c}-2.006^{* * *} \\
{[-11.56]}\end{array}$ \\
\hline$\Delta$ Dividends & $\begin{array}{c}2.149^{* * *} \\
{[8.79]}\end{array}$ & $\begin{array}{c}2.117^{* * *} * \\
{[8.66]}\end{array}$ & $\begin{array}{c}1.280^{* * *} \\
{[5.06]}\end{array}$ & $\begin{array}{c}2.197^{* * *} \\
{[8.89]}\end{array}$ \\
\hline Cash holdings $_{t-1}$ & $\begin{array}{c}0.384^{* * *} \\
{[26.28]}\end{array}$ & $\begin{array}{c}0.440^{* * *} \\
{[27.77]}\end{array}$ & $\begin{array}{c}0.491 * * * \\
{[26.11]}\end{array}$ & $\begin{array}{c}0.362^{* * * *} \\
{[24.70]}\end{array}$ \\
\hline Leverage & $\begin{array}{c}-0.451^{* * *} \\
{[-44.42]}\end{array}$ & $\begin{array}{c}-0.536 * * * \\
{[-45.75]}\end{array}$ & $\begin{array}{c}-0.370 * * * \\
{[-31.07]}\end{array}$ & $\begin{array}{c}-0.457^{* * *} \\
{[-43.68]}\end{array}$ \\
\hline Net financing & $0.048^{* *}$ & $0.061^{* * *}$ & $0.180^{* * *}$ & $0.041^{* *}$ \\
\hline Constant & $\begin{array}{c}-0.081^{* * *} * \\
{[-14.03]}\end{array}$ & $\begin{array}{l}-0.019 \\
{[-0.61]}\end{array}$ & $\begin{array}{c}-0.617^{* * *} * \\
{[-14.30]}\end{array}$ & $\begin{array}{c}-0.056^{* * *} \\
{[-5.11]}\end{array}$ \\
\hline Observations & 67,404 & 67,404 & 67,404 & 67,404 \\
\hline$R^{2}$-adjusted & 0.192 & 0.202 & 0.192 & 0.187 \\
\hline Year fixed effects & No & Yes & No & Yes \\
\hline Industry fixed effects & No & Yes & No & Yes \\
\hline
\end{tabular}




\section{Table 11. Re-examination of the relation between $M M I O_{1}$ and the value of}

cash across three cash regimes

This table reports the 2SLS regressions of firm excess returns on changes in cash holdings, proxies for most motivated monitoring IO, the interaction of the prior two variables, and control variables. The sample consists of 67,404 firm-year observations of US firms over the sample period 1995-2015 with required data for the regressions. $\Delta$ indicates the change in the corresponding variable from year $t-1$ to $t$. Column (1) reports the first stage regression results. The dependent variable in the first stage regression is $M M I O_{1}$. The IVs used are the same as those used in Panel A of Table 7. Columns (2)-(4) report the second stage regression results. The dependent variable in the second stage regression is $r_{i t}-R_{i t}^{B}$, the annual excess stock return relative to the Fama and French (1993) 25 size and book-tomarket portfolios. The independent variables of interest in the second stage regressions are $I V M M I O_{1}$, the predicted $M M I O_{1}$ by the first stage regressions, and its interaction with $\Delta$ Cash holdings. We follow Halford et al. (2016) and define three cash regimes. Firms in the raising cash regime issue equity and do not pay dividends, firms in the distributing cash regime pay dividends or repurchase equity, and firms in the servicing debt regime have market leverage ratio in the top decile of all firms and do not raise or distribute cash. All regressions include controls for calendar year fixed effects and Fama-French 48 industry fixed effects whose coefficients are suppressed for brevity. Detailed definitions of all variables are described in Appendix A. Standard errors are clustered at the firm level. t-statistics are reported in brackets. $*, * *$, and $* * *$ denote statistical significance at the $10 \%, 5 \%$, and $1 \%$ level, respectively.

\begin{tabular}{|c|c|c|c|c|}
\hline \multirow[b]{2}{*}{ Variables } & \multirow{2}{*}{$\begin{array}{c}\text { First stage } \\
M M I O_{1} \\
\\
(1)\end{array}$} & \multicolumn{3}{|c|}{$\begin{array}{l}\text { Second stage } \\
\quad r_{i t}-R_{i t}^{B}\end{array}$} \\
\hline & & $\begin{array}{c}\text { Raising cash } \\
\text { (2) }\end{array}$ & $\begin{array}{c}\text { Distributing cash } \\
(3)\end{array}$ & $\begin{array}{c}\text { Servicing debt } \\
\text { (4) }\end{array}$ \\
\hline IVMMIO $\mathrm{O}_{1} \times \Delta$ Cash holdings & & $\begin{array}{c}3.872^{* * *} \\
{[4.10]}\end{array}$ & $\begin{array}{c}1.550^{* *} \\
{[2.43]}\end{array}$ & $\begin{array}{l}1.522 \\
{[1.60]}\end{array}$ \\
\hline$I V M M I O_{1}$ & & $\begin{array}{c}1.204^{* * *} \\
{[3.23]}\end{array}$ & $\begin{array}{l}0.233 \\
{[1.14]}\end{array}$ & $\begin{array}{l}-1.816^{*} \\
{[-1.67]}\end{array}$ \\
\hline$R 1 T R 2$ & $\begin{array}{c}0.011^{* *} \\
{[2.21]}\end{array}$ & & & \\
\hline$R 2 T N$ & $\begin{array}{c}-0.056^{* * *} \\
{[-20.55]}\end{array}$ & & & \\
\hline$R 2 T R 1$ & $\begin{array}{c}0.073 * * * \\
{[13.00]}\end{array}$ & & & \\
\hline$N T R 2$ & $\begin{array}{c}-0.064 * * * \\
{[-21.30]}\end{array}$ & & & \\
\hline$\Delta$ Cash holdings & $\begin{array}{c}0.028 * * * \\
{[5.54]}\end{array}$ & $\begin{array}{c}1.469^{* * *} \\
{[15.97]}\end{array}$ & $\begin{array}{c}0.839^{* * *} \\
{[12.19]}\end{array}$ & $\begin{array}{c}0.487^{* * *} \\
{[5.03]}\end{array}$ \\
\hline$\Delta$ Earnings & $\begin{array}{c}-0.004^{* *} \\
{[-2.47]}\end{array}$ & $\begin{array}{c}0.418^{* * * *} \\
{[9.22]}\end{array}$ & $\begin{array}{c}0.564^{* * *} \\
{[18.28]}\end{array}$ & $\begin{array}{c}0.308^{* * *} \\
{[7.45]}\end{array}$ \\
\hline$\Delta$ Net assets & $\begin{array}{c}0.039^{* * *} \\
{[20.07]}\end{array}$ & $\begin{array}{c}0.219^{* * * *} \\
{[6.84]}\end{array}$ & $\begin{array}{c}0.182^{* * * *} \\
{[10.04]}\end{array}$ & $\begin{array}{c}0.103^{* *} \\
{[2.30]}\end{array}$ \\
\hline$\Delta R \& D$ & $\begin{array}{c}0.092^{* * *} \\
{[4.40]}\end{array}$ & $\begin{array}{c}0.755^{* *} \\
{[2.56]}\end{array}$ & $\begin{array}{c}1.154^{* * * *} \\
{[3.42]}\end{array}$ & $\begin{array}{l}1.138 \\
{[1.18]}\end{array}$ \\
\hline
\end{tabular}

Continued on next page 
Table 11 - continued from previous page

\begin{tabular}{|c|c|c|c|c|}
\hline \multirow[b]{2}{*}{ Variables } & \multirow{2}{*}{$\begin{array}{c}\text { First stage } \\
M M I O_{1} \\
(1)\end{array}$} & \multicolumn{3}{|c|}{$\begin{array}{l}\text { Second stage } \\
\quad r_{i t}-R_{i t}^{B}\end{array}$} \\
\hline & & $\underset{\text { (2) }}{\text { Raising cash }}$ & $\begin{array}{c}\text { Distributing cash } \\
(3)\end{array}$ & $\begin{array}{l}\text { Servicing debt } \\
\text { (4) }\end{array}$ \\
\hline$\Delta$ Interest expenses & $\begin{array}{l}0.019 \\
{[0.78]}\end{array}$ & $\begin{array}{l}-0.780 \\
{[-1.63]}\end{array}$ & $\begin{array}{c}-2.200^{* * *} \\
{[-6.82]}\end{array}$ & $\begin{array}{c}-0.714^{* *} \\
{[-2.26]}\end{array}$ \\
\hline$\Delta$ Dividends & $\begin{array}{c}0.536^{* * *} \\
{[9.30]}\end{array}$ & $\begin{array}{c}3.785 * * * \\
{[2.98]}\end{array}$ & $\begin{array}{c}2.195^{* * *} \\
{[7.08]}\end{array}$ & $\begin{array}{l}1.234 \\
{[0.73]}\end{array}$ \\
\hline Cash holdings ${ }_{t-1}$ & $\begin{array}{c}-0.110 * * * \\
{[-19.92]}\end{array}$ & $\begin{array}{c}1.012^{* * *} \\
{[16.40]}\end{array}$ & $\begin{array}{c}0.265^{* * *} \\
{[8.37]}\end{array}$ & $\begin{array}{c}0.313^{* *} \\
{[2.47]}\end{array}$ \\
\hline Leverage & $\begin{array}{c}-0.051^{* * *} \\
{[-7.71]}\end{array}$ & $\begin{array}{c}-0.918^{* * *} \\
{[-19.25]}\end{array}$ & $\begin{array}{c}-0.375 * * * \\
{[-19.92]}\end{array}$ & $\begin{array}{c}-1.861 * * * \\
{[-8.26]}\end{array}$ \\
\hline Net financing & $\begin{array}{c}-0.076 * * * \\
{[-17.37]}\end{array}$ & $\begin{array}{c}0.124^{* *} \\
{[2.01]}\end{array}$ & $-0.140 * * *$ & $\begin{array}{c}-0.165^{*} \\
{[-1.71]}\end{array}$ \\
\hline Constant & $\begin{array}{c}0.094^{* * *} \\
{[3.67]}\end{array}$ & $\begin{array}{l}0.092 \\
{[0.67]}\end{array}$ & $\begin{array}{l}-0.014 \\
{[-0.32]}\end{array}$ & $\begin{array}{c}0.970^{* * *} \\
{[4.28]}\end{array}$ \\
\hline Observations & 63,973 & 8,782 & 27,563 & 1,579 \\
\hline$R^{2}$-adjusted & 0.108 & 0.263 & 0.173 & 0.341 \\
\hline Year fixed effects & Yes & Yes & Yes & Yes \\
\hline Industry fixed effects & Yes & Yes & Yes & Yes \\
\hline
\end{tabular}




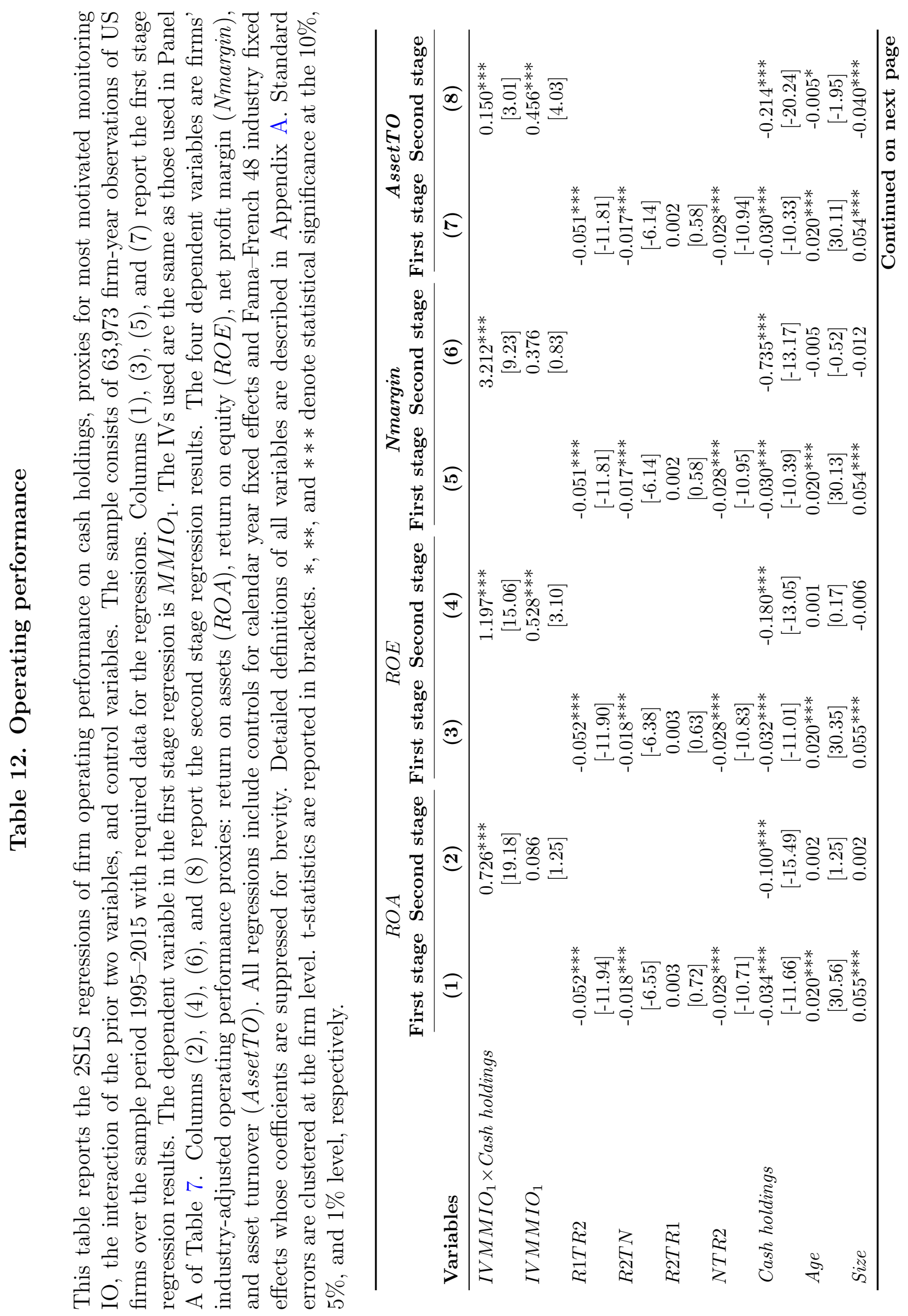




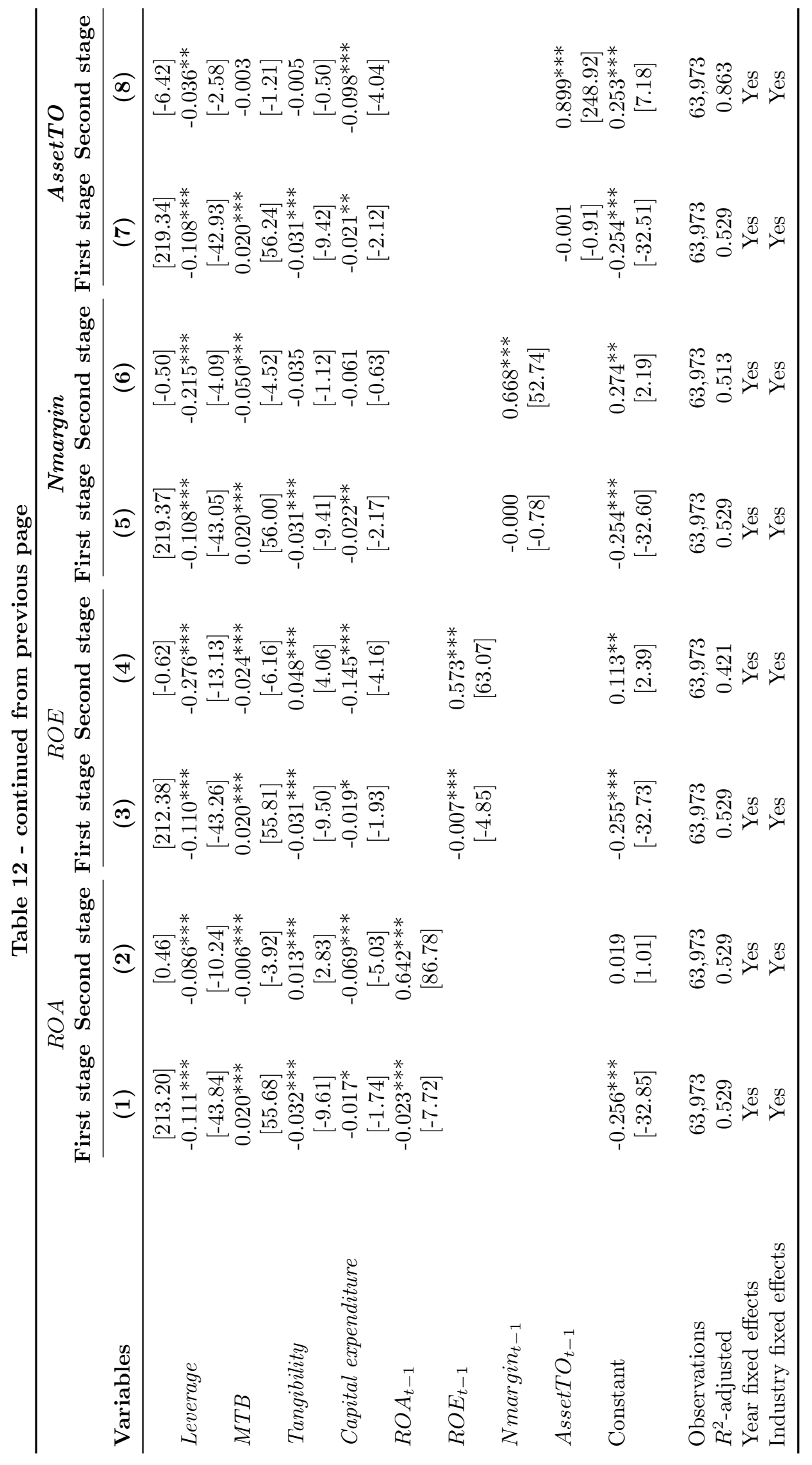




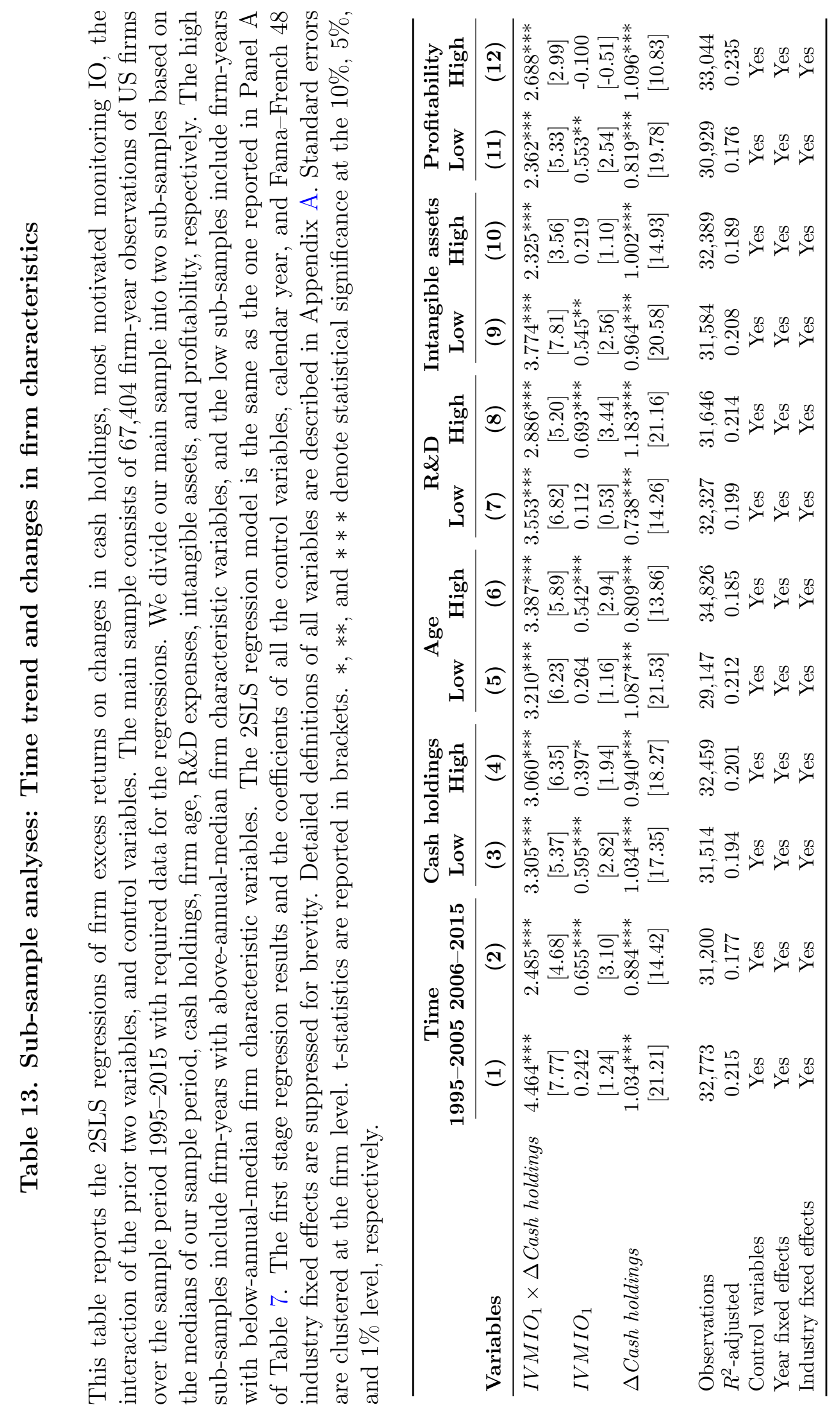

